Reubi, O., Ross, P.-S. et White, J.D.L. (2005) Debris avalanche deposits associated with Large Igneous province volcanism: an example from the Mawson Formation, Central Allan Hills, Antarctica. Geological Society of America Bulletin 117: 1615-1628

\title{
Debris avalanche deposits associated with large igneous province volcanism: an example from the Mawson Formation, central Allan Hills, Antarctica
}

\author{
O. Reubi ${ }^{1,2,3}, P-S$. Ross $^{1,2,4}$ and J.D L. White ${ }^{1}$
}

1. Department of Geology, University of Otago, PO Box 56, Dunedin, New Zealand.

2. These authors contributed equally to this work.

3. Now at: Institut de Minéralogie et Pétrographie, Section des Sciences de la Terre, Université de Lausanne, BFSH-2, CH-1015 Lausanne, Switzerland.

4. Corresponding author.

\begin{abstract}
An up to $180 \mathrm{~m}$-thick debris avalanche deposit related to Ferrar large igneous province magmatism is observed at central Allan Hills, Antarctica. This Jurassic debris avalanche deposit forms the lower part (member $\left.m_{1}\right)$ of the Mawson Formation and is overlain by thick volcaniclastic layers containing a mixture of basaltic and sedimentary debris $\left(\right.$ member $\mathrm{m}_{2}$ ). The $\mathrm{m}_{1}$ deposit consists of a chaotic assemblage of breccia panels and megablocks up to $80 \mathrm{~m}$ across. In contrast to $\mathrm{m}_{2}$, it is composed essentially of sedimentary material derived from the underlying Beacon Supergroup. The observed structures and textures suggest that the breccias in $\mathrm{m}_{1}$ were mostly produced by progressive fragmentation of megablocks during transport but also to a lesser extent by disruption and ingestion of the substrate by the moving debris avalanche. The upper surface of the debris avalanche deposit lacks large hummocks, and sandstone breccias dominate volumetrically over megablocks within the deposits. This indicates pervasive and relatively uniform fragmentation of the moving mass, and probably reflects the weak and relatively homogenous nature of the material involved. The avalanche flowed into a pre-existing topographic depression carved into the Beacon sequence, and flow indicators reveal a northeastward movement. The source area is probably now hidden under the Antarctic ice sheet. Sparse basaltic bodies, which were hot and plastic during transport in $\mathrm{m}_{1}$, reveal the role of Ferrar magmatism in triggering the avalanche, possibly in relation to the emplacement of large sub-surface intrusions. The documented deposits indicate that debris avalanches are among the various phenomena that can accompany the early stages of large igneous province magmatism, despite the common absence of large central volcanic edifices. Where large igneous provinces develop in association with faulting, or slow pre-eruptive uplift accompanied by deep valley incision, there is a high probability that feeder dikes will approach the surface in areas of steep topography, allowing volcano-seismicity and fluid overpressures associated with intrusion to effectively trigger avalanches.
\end{abstract}

\section{INTRODUCTION}

Debris avalanches, also known as Sturzstroms, result from sudden collapses of large volumes of rock (typically 0.1 to $50 \mathrm{~km}^{3}$ ) that affect the flanks of mountains, including volcanoes (Hsü, 1978; Ui, 1983; Siebert, 1984). Debris avalanches are high-speed mass movements that start as landslides and transform into granular flows during transport as a result of internal fragmentation (Voight et al., 1983; Glicken, 1991). They are characterized by high mobility, which is reflected by horizontal travel distances 3 to 20 times greater than the vertical travel distances or vertical drop (Ui, 1983; Voight et al., 1985). The actual mechanism allowing the high mobility of debris avalanches is still under consideration; proposed emplacement models include an "hovercraft" air-layer lubrication mechanism, a mechanical fluidization model (based on dispersive grain flow), a mass loss model, a seismic energy fluidization model, etc., and address both dry and water-bearing rock (see Ui et al., 2000, and Legros 2002 for reviews). In volcanic settings, debris avalanches are common occurrences at stratovolcanoes where steep topography and rapid accumulation of lava flows on top of friable volcaniclastic material promote instabilities. In this paper we describe a debris avalanche related to the emplacement of a mafic large igneous province, an unusual setting for this type of event.

Large igneous provinces are often thought to consist exclusively of lava flows and shallow intrusions, but mafic volcaniclastic deposits are increasingly recognized to form a significant component (e.g., Elliot, 2000; Jerram, 2002; Ukstins Peate et al., 2003; Ross et al., 2005 and references therein). These mafic volcaniclastic rocks are commonly interpreted to have a phreatomagmatic origin and include tuff rings, hyaloclastite deltas, vent-filling lapilli-tuffs, and the 
deposits of pyroclastic density currents and lahars, but to our knowledge, no debris avalanche deposits have been previously documented in association with them, or with large igneous provinces. We have identified a debris avalanche deposit associated with the Ferrar large igneous province at Allan Hills, Antarctica; our aim here is to review the characteristics of this deposit, discuss its origin, and outline possible implications for the emplacement of the Ferrar province and large igneous province volcanism in general.

\section{GEOLOGICAL SETTING}

The Ferrar large igneous province outcrops principally in the Transantarctic Mountains (Fig. 1a), with correlatives in southern Australia and New Zealand (Elliot, 1992; Mortimer et al., 1995; Brauns, 2000; Hergt and Brauns, 2001). The Ferrar belongs to a group of Jurassic magmatic provinces which also includes the Karoo (Southern Africa) and the Chon Aike (South America and Antarctic Peninsula). Preserved flood lavas in the Ferrar province (the Kirkpatrick Basalt; Grindley, 1963; Elliot, 1972; Fleming et al., 1992; Heimann et al., 1994; Elliot et al., 1999) are subordinate to shallow intrusions (Ferrar Dolerite), with lava outcrops scattered in three widely spaced regions spread over $1300 \mathrm{~km}$ in the Transantarctic Mountains (Fig. 1a). The cumulative thickness of lavas varies from 380 to $780 \mathrm{~m}$. The Kirkpatrick Basalt is generally underlain by a 10 to $>400$ m-thick sequence of mafic volcaniclastic rocks (Elliot, 2000). Within individual regions, the thickness of volcaniclastic rocks varies widely over tens of kilometers, suggesting that either (i) local eruptive centers produced thick localized volcaniclastic accumulations, possibly for the most part in depressions excavated by volcanic activity (White and McClintock, 2001; Elliot et al., 2004) or (ii) there existed significant pre-eruption topography, perhaps created by extensional tectonics not related to volcanic activity (Elliot and Larsen, 1993; Elliot and Hanson, 2001).

In South Victoria Land, the Jurassic mafic volcaniclastic rocks are assigned to the Mawson Formation (Gunn and Warren, 1962; Borns et al., 1969; Ballance and Watters, 1971; Grapes et al., 1974; Korsch, 1984; Bradshaw, 1987; Elliot and Hanson, 2001; McClintock, 2001). The Mawson deposits intrude and overlie a sequence of mostly continental DevonianTriassic sedimentary rocks, the Beacon Supergroup (Barrett, 1991; Bradshaw, 1991; Collinson et al., 1994). Only the top three formations of the Beacon Supergroup are present at Allan Hills. From oldest to youngest, these are the Weller Coal Measures (WCM), the Feather Sandstone, and the Lashly Formation, all dominated by sandstone beds. Stratigraphic and petrographic studies of these formations were presented by Barrett and Kohn (1975), Ballance (1977), Collinson et al. (1983) and Bornholdt (2001). The Weller Coal Measures $(250 \mathrm{~m}$ thick) are characterized by repeated fining-upward sequences of pebbly sandstone, medium sandstone, carbonaceous fine sandstone to siltstone, and coal. The Lower Feather Sandstone (120 m thick) consists of coarse to pebbly, planar- to cross-bedded sandstone with rare beds of fine sandstone and siltstone. The Upper Feather Sandstone (53 m thick) comprises interbedded fine to coarse sandstone and siltstone. Sandstones in the Weller Coal Measures and the Lower Feather Sandstone are very quartzitic, whereas those in the Upper Feather Sandstone and Lashly Formation include more lithic fragments. The Lashly Formation has been divided into four members: (A) alternating sandstone and greenish to gray mudstone (49 $\mathrm{m}$ thick), (B) massive sandstone (54 m thick), (C) alternating coal measures, greenish to gray mudstone and fine sandstone (137 $\mathrm{m}$ thick) and (D) medium to coarse grained quartzitic sandstone $(85 \mathrm{~m}$ thick). The sandstones in members $\mathrm{A}, \mathrm{B}$ and $\mathrm{C}$ are impure and distinctively include volcanic fragments.

We formally subdivide the Mawson Formation at Allan Hills into two members: $m_{1}$ consisting almost exclusively of Beacon fragments (and interpreted as a debris avalanche deposit) and $\mathrm{m}_{2}$ characterized by abundant (20-85\%) basaltic material. In southern and central Allan Hills, $\mathrm{m}_{2}$ consists principally of $\sim 1-15 \mathrm{~m}-$ thick volcaniclastic layers dominated by poorly sorted, internally structureless coarse lapilli-tuffs and tuffbreccias (Ross and White, 2005). At nearby Coombs Hills, the composition and texture of the Mawson Formation is similar, but no layering is observed except near the top, and the deposits are interpreted to fill a $>5 \mathrm{~km}$-wide vent complex (McClintock, 2001; White and McClintock, 2001; Ross, 2005, Ross and White, submitted). Deposits similar to $\mathrm{m}_{2}$ in composition are volumetrically dominant in Mawson correlatives in North Victoria Land (Elliot et al., 1986), the Prince Albert Mountains (Elliot, 2002), and the Central Transantarctic Mountains (Hanson and Elliot, 1996; Elliot and Hanson, 2001). Overall, $\mathrm{m}_{2}$ deposits and correlatives are interpreted as the products of explosive interaction between rising basaltic magma and wet sediment or weakly consolidated sedimentary rocks (mostly the top half of the Beacon Supergroup) (Hanson and Elliot, 1996; Elliot and Hanson, 2001; White and McClintock, 2001). A hydromagmatic origin is inferred for most mafic volcaniclastic deposits associated with large igneous provinces (Ross et al., 2005). The dominant transport mechanism for $\mathrm{m}_{2}$-type Mawson deposits is subject to debate, and certainly varies among localities. For different sites, various authors favor horizontal transport in lahars or pyroclastic density currents filling pre-existing depressions (Elliot, 2000; Elliot and Hanson, 2001; Ross and White, 2005) or vertical transport in volcanic vents (White and McClintock, 2001; McClintock and White, 2005; Ross and White, submitted).

The $\mathrm{m}_{1}$ member has been observed only at central Allan Hills (Fig. 2a). Both Ballance and Watters (1971) and Elliot and Hanson (2001) noted the abundance of sedimentary material in the lower part of the formation at Allan Hills (our $\mathrm{m}_{1}$ member), but assigned a common laharic or mudflow origin to the whole formation. To explain the great abundance of Beacon material in the lower part of the Mawson Formation $\left(\mathrm{m}_{1}\right)$, Ballance and Watters (1971) proposed that "the lower portions of the mudflow(s) picked up a great deal of Beacon Group debris as it (they) moved into the valley". Recently, Bornholdt (2001), Lockett and White (2002), Lockett (2003) and Elliot et al. (2004) suggested that the Mawson Formation on northern Mt 
Watters represent vent-filling phreatomagmatic deposits and debris avalanche deposits produced by collapse of the vent walls. As part of this study, we reinvestigated $\mathrm{m}_{1}$ on the flanks of Mt Watters and extended our observations to the western sector of central Allan Hills. We propose that $m_{1}$ represents a voluminous debris avalanche that mobilized the top of the Beacon Supergroup (mostly the Lashly Formation), probably as a result of intrusion of Ferrar dikes, and spread northeastward in a preexisting topographic trough.

\section{OBSERVATIONS}

\section{Geometry and volume of $\mathbf{m}_{1}$}

The contact between $\mathrm{m}_{1}$ and the substrate (Beacon Supergroup) varies in altitude from $\sim 1800 \mathrm{~m}$ a.s.l. in Feistmantel Valley to slightly over $1900 \mathrm{~m}$ on the north slope of Mt Watters (Figs. $2 \& 3$ ). The geometry of the contact suggests that the Feistmantel Valley area was already a topographic depression at the time $\mathrm{m}_{1}$ was deposited (Ballance and Watters, 1971; section A-A' on Fig. 2). Lashly Formation (member D?) crops out at $\sim 2030 \mathrm{~m}$ a.s.1. on Roscollyn Tor, $5 \mathrm{~km}$ northeast of Feistmantel Valley (Fig. 3), implying that the depression was demonstrably at least $230 \mathrm{~m}$ deep, relative to flanking highlands on the northeast side. The trough was almost certainly somewhat deeper, because the top of the Lashly Formation is eroded at Roscollyn Tor, and an overlying formation or member containing silicic tuffs, equivalent to the Hanson Formation in the Central Transantarctic Mountains and preserved as clasts at Coombs Hills, has been removed (Elliot, 1996; Elliot et al., 2004); Collinson et al. (1983) suggested a depression $500 \mathrm{~m}$ deep.

The $\mathrm{m}_{1}$ deposits are covered by volcaniclastic layers $\left(\mathrm{m}_{2}\right)$ that display sub-horizontal bedding at outcrop scale. The altitude of the contact with $\mathrm{m}_{2}$ and the thickness of $\mathrm{m}_{1}$ vary at kilometer scale (Fig. 2), indicating a gently undulating upper surface for $\mathrm{m}_{1}$. The maximum thickness observed for $\mathrm{m}_{1}$, about $180 \mathrm{~m}$, is on the northwest flank of Mt Watters (section B-B' on Fig. 2).

Member $\mathrm{m}_{1}$ is exposed over approximately 8.7 $\mathrm{km}^{2}$ in central Allan Hills; assuming, for simplicity, a uniform thickness of $180 \mathrm{~m}$ gives an inferred original volume of about $1.6 \mathrm{~km}^{3}$ for the exposure area alone. It appears very likely (but cannot be proven) that $\mathrm{m}_{1}$ extends at least some distance under $\mathrm{m}_{2}$ in southern Allan Hills, which would increase the inferred $\mathrm{m}_{1}$ volume to at least $2 \mathrm{~km}^{3}$.

\section{Internal characteristics of the $m_{1}$ member}

The deposit of interest can be described overall as a chaotic assemblage of breccia panels and megablocks. The latter, which are by convention $>2 \mathrm{~m}$ in size and may not be angular in shape, represent a small but ubiquitous portion $(<10 \%)$ of $\mathrm{m}_{1}$ (Fig. 4). Although megablocks are found dispersed throughout the member, their distribution is not uniform, and a zone of accumulation is observed on the northern side of Mt Watters (Figs. 2b, 5). Three lithological types of megablocks may be distinguished there (Table 1); the character of megablocks present in Feistmantel Valley is summarized in Table 2.
Sandstone breccias, with or without megablocks, constitute $90-95 \%$ of the $\mathrm{m}_{1}$ member. In detail, breccias show highly variable textures and compositions. Four principal types are distinguished according to their componentry, granulometry, contact geometries, and relationship (or lack of) with megablocks; these are labeled $\mathrm{BX} 1$ to $\mathrm{BX} 4$. The distribution of the breccia types is shown on figure $2 b$, photographs are presented in figure 6 and summary descriptions are given in Table 2. Figure 7 shows the point-counted size distribution and componentry for two of these types.

Although four types of breccia can be distinguished, the contacts between them are generally difficult to draw. The transitions from one type to another are progressive and can occur over distances varying from a few tens of centimeters to hundreds of meters.

\section{Deformation of the substrate}

Two different styles of substrate deformation are observed where $\mathrm{m}_{1}$ lies on Weller Coal Measures (WCM) versus Feather Sandstone. In Feistmantel Valley, where $\mathrm{m}_{1}$ overlies interbedded sandstone, siltstone and coal of the Weller Coal Measures, the contact is sharp and erosive. The top $1-5 \mathrm{~m}$ of the substrate is slightly fractured to totally brecciated, and locally folded. WCM clasts are often incorporated within $\mathrm{m}_{1}$, forming trails that indicate transport toward the northeast (Fig. 8). Where WCM beds have been folded, the folds have amplitudes between 1 and $5 \mathrm{~m}$ and have north-northwest trending axes and subvertical axial planes, perpendicular to the inferred transport direction of $\mathrm{m}_{1}$ (Fig. 9). Deformation within the WCM is principally in the form of fragmentation and block rotations. The WCM beds are only deformed at the contact with $\mathrm{m}_{1}$, indicating that the folds and fractures are related to emplacement of the member and result from compression, ephemeral dilation (Pollet and Schneider 2004), and shear of the substrate by the moving mass of debris.

On northern Mt Watters, where $\mathrm{m}_{1}$ lies on medium to pebbly sandstones and siltstones of the lower Feather Formation, the contact is gradational. Nondeformed cross-bedded sandstones pass vertically to in situ brecciated sandstones and ultimately to matrixsupported breccias (BX3) (Fig. 5). Within the more intensely in situ brecciated sandstones, the original bedding has been almost completely erased and only crude variations in grain size can be observed (Fig. 10a). The original beds now form wavy horizons. Siltstone interbeds are fragmented, tilted and slightly dispersed but still form recognizable levels. Locally, sandstone beds are brecciated and the fragments tilted (Fig. 10b). The tilted fragments systematically dip toward the eastnortheast (Fig. 11). Disruption of the sandstones is generally not continuous upward. Tilted fragments with almost no matrix between them, as in figure $10 \mathrm{~b}$, often lie on disrupted wavy horizons (Fig. 10a). The in situ brecciated sandstones grade progressively upwards into typical BX3 breccias with $60-90 \%$ sandy matrix. The transition from non-deformed sandstone to BX3 occurs generally over $2-3 \mathrm{~m}$ vertically (locally up to $5 \mathrm{~m}$ ). 
These features suggest that shearing at the base of the flow that deposited $m_{1}$ resulted in the rotation of the fragments within the in situ brecciated level of Feather Sandstone; the orientation of these rotated domains implies a transport direction toward the east-northeast in accordance with the structures observed at lower elevations in Feistmantel Valley.

\section{ORIGIN OF $\mathrm{m}_{1}$ DEPOSITS}

In summary, important characteristics of $m_{1}$ at central Allan Hills are: (1) an absence of bedding in a chaotic deposit up to $180 \mathrm{~m}$ thick; (2) the presence of megablocks up to $80 \mathrm{~m}$ in size; (3) fragmentation of the megablocks, which often show jigsaw textured cores; (4) the presence of distinct breccia domains with lateral and vertical gradations; and (5) dispersion of the fragments from the megablock rims into the surrounding breccias. Such features are ubiquitous in debris avalanche deposits, both in non-volcanic and volcanic settings (Shreve, 1968; Ui, 1983; Siebert, 1984; Glicken, 1991; Abbott et al., 2002). This very strongly suggests that $\mathrm{m}_{1}$ represents the deposits of a debris avalanche.

Elliot and Hanson (2001) proposed a phreatomagmatic origin for the whole of the Mawson Formation at Allan Hills. Except for portions of BX1 where large basaltic bodies are found, however, $\mathrm{m}_{1}$ lacks glassy basaltic fragments, and has no dispersed ones of ash and lapilli size. In the absence of widely dispersed small fragments representing newly fragmented magma (or even recycled magmatic clasts), there is no reason to interpret $\mathrm{m}_{1}$ as "phreatomagmatic", or even "pyroclastic". In $\mathrm{m}_{2}$ and other demonstrably phreatomagmatic deposits, juvenile clasts of ash and lapilli size are intimately mixed with accidental material, or the deposits consist almost exclusively of juvenile material.

The similitude in lithology between the sedimentary fragments within BX1 and BX2 and the megablocks enclosed in these breccias, as well as the observed progressive dispersion of the fragmented megablocks, suggest that $\mathrm{BX} 1$ and $\mathrm{BX} 2$ represent the final products of megablock disaggregation during transport within a debris avalanche. BX3 breccias differ in that they do not host megablocks of similar lithology, but instead resulted from fragmentation and mobilization of the Lower Feather Sandstone in response to the passage of the debris avalanche (details below). BX4 breccias also result at least partly from fragmentation of the substrate by the overriding debris avalanche and incorporation of Weller Coal Measures clasts and megablocks.

Large ovoid to spherical basaltic bodies in $\mathrm{m}_{1}$ are not extensively internally fragmented, as opposed to sedimentary megablocks in $\mathrm{m}_{1}$ and lava megablocks in other debris avalanche deposits (e.g. Ui, 1983; Siebert, 1984; Glicken, 1991; Reubi and Hernandez, 2000). We suggest that these basaltic bodies were hot and plastic during transport based on their shape, lack or low degree of fragmentation, and the common presence of a chilled margin. The most likely source for these bodies would be dikes or sills emplaced within the Beacon Supergroup shortly before or at the time of debris avalanche initiation (Fig. 12a). During transport, disruption of the moving mass would result in separation of the stillplastic basalt into multiple domains and their dispersion within the breccias being formed at the same time by fragmentation of the Beacon Supergroup sedimentary rocks (Fig. 12b). The presence of these basalt bodies in $\mathrm{m}_{1}$ clearly demonstrates an incidental relationship between the debris avalanche and the emplacement of the Ferrar large igneous province, the only magmatic event known to have occurred in this region at the time of $\mathrm{m}_{1}$.

\section{Source area of the debris avalanche}

The lithology of the sedimentary megablocks within $\mathrm{m}_{1}$ indicates that the initial slope failure released Lashly Formation, probably members C and D and the overying silicic tuff layers (Fig. 12a). The inferred transport direction for the debris avalanche - toward the northeast - would suggest a source situated roughly southwest from the deposits. Debris avalanches flowing in constricted topography, however, can be deviated strongly by transverse walls (e.g. Francis and Wells, 1988; Glicken, 1991; Schneider et al., 1999). Consequently we can only infer that the source is situated in the sector southeast to northwest of central Allan Hills. Thick glaciers now cover most of this region (Fig. 1b), and none of the isolated outcrops in the area south of Allan Hills expose Beacon rocks; the source of the debris avalanche cannot be more precisely located. In southern Allan Hills, $\mathrm{m}_{2}$ crops out down to $\sim 1915 \mathrm{~m}$ a.s.l., and the base of the Mawson is not visible (Grapes et al., 1974; Ross and White, 2005), indicating that it is an improbable location for the source. At Coombs Hills, $\sim 10 \mathrm{~km}$ southeast of central Allan Hills (Fig. 1b), the Lashly Formation outcrops to $\sim 2000 \mathrm{~m}$ in altitude (Grapes et al., 1974). If the source were situated there, it would imply a travel distance (L) of $\sim 13 \mathrm{~km}$ for a vertical drop $(\mathrm{H})$ of $\sim 100 \mathrm{~m}$, which gives a Heim coefficient $\mathrm{H} / \mathrm{L}$ of 0.007 far under that observed for other volcanic and non-volcanic DAs, which have $\mathrm{H} / \mathrm{L}$ ratios between 0.05 and 0.3 (Ui, 1983; Voight et al., 1985). If a $\mathrm{H} / \mathrm{L}$ ratio of 0.05 is assumed, the source would have been located within $4 \mathrm{~km}$ of the observed deposits if the Lashly Formation occurred at a maximum altitude of $2000 \mathrm{~m}$. The Lashly Formation may have occurred at a higher altitude in the sector southeast of central Allan Hills, however, as suggested by the presence of sandstone rafts in the Mawson Formation at least $2250 \mathrm{~m}$ a.s.l. at Coombs Hills. These rafts are inferred to have slumped from the vent walls within a large phreatomagmatic vent complex (White and McClintock, 2001). With a potential $\mathrm{H}$ as great as $500 \mathrm{~m}$, a $\mathrm{H} / \mathrm{L}$ ratio of 0.05 would allow a source as much as $10 \mathrm{~km}$ from present outcrops.

\section{Trigger mechanism}

As nothing is known about the topographic and structural configuration of the source area, the causes of structural failure that produced the debris avalanche remain speculative. The $m_{1}$ deposits consist of $>90 \%$ Beacon Supergroup sedimentary material, which implies that the volume that collapsed was not a volcanic edifice, but the upper portion of the Beacon Supergoup. Factors that may have contributed to the collapse could include 
steep dip slopes of Beacon rocks, or oversteepened topography. The first hypothesis is unlikely, because observed Beacon strata are generally sub-horizontal (except locally above some Ferrar sills) and no tectonic event that would have resulted in extensive tilting is known to have affected this region after deposition of the Beacon Supergroup. The Mawson Formation is inferred to have been deposited within basins formed by regional extension (Elliot and Hanson, 2001). In this context, oversteepening produced by normal faulting may be the most likely cause of slope instability (Fig. 12a). The presence of large basaltic bodies within $\mathrm{m}_{1}$ suggests that emplacement of dikes and sills within the Beacon may be a factor that contributed to the collapse. A relationship between magma injection and landsliding is commonly observed in volcanic environments (e.g. Siebert, 1984; McGuire, 1996; Masson et al., 2002). Dikes may promote collapse as a result of displacements related to magma injection, associated seismic activity, or by increasing pore pressure of groundwater in surrounding rocks (Siebert, 1984, Day, 1996; Elsworth and Voight, 1996). In summary, we suggest that a combination of normal faulting and contemporaneous emplacement of shallow intrusions is the most likely cause of the catastrophic collapse that produced the debris avalanche deposits observed in central Allan Hills.

\section{PARTICULARITIES OF THE $m_{1}$ DEBRIS AVALANCHE}

The debris avalanche deposit studied differs from others in lacking evidence for a hummocky surface; containing relatively few megablocks, particularly in its upper part; and having relatively strong interactions with substrate rocks.

\section{Lack of hummocks}

The $\mathrm{m}_{1}-\mathrm{m}_{2}$ contact, representing the upper surface of the debris avalanche deposit, is relatively flat, displaying no significant hummocks (Fig. 12c). The lack of hummocks is unusual among debris avalanche deposits, particularly examples related to volcanic edifices, which show hummocky surface morphologies (Ui, 1983; Siebert, 1984; Glicken, 1991). Where they exist in other debris avalanche deposits hummocks mostly consist of variably fragmented megablocks, and their size often decreases away from the source, suggesting that they represent domains of the collapsed mass that are progressively broken up into smaller megablocks during transport (Ui, 1983; Siebert, 1984; Clavero et al., 2002). Although not common, debris avalanche deposits lacking hummocks have been described previously (e.g., Naranjo and Francis, 1987; Francis and Wells, 1988; Reubi and Hernandez, 2000). The primary control on the surface morphology of debris avalanche deposits is inferred to be the nature of the landslide material. Debris avalanche deposits consisting of weak material (mostly pyroclastic fragments for volcanic cases) show gently undulating surfaces, whereas those consisting of stronger material show pronounced hummocky surfaces (e.g. Naranjo and Francis, 1987; Reubi and Hernandez, 2000). In the $\mathrm{m}_{1}$ case, the yellow sandstone megablocks present in the top portion of the debris avalanche deposits (Fig. 5) have complex shapes, and form flame structures in the surrounding breccias - this suggests that they were poorly consolidated during transport and behaved in an almost fluid-like manner. The presence of such weak material in the upper parts of the collapsed section is likely to be an important factor in the apparent absence of hummocks.

\section{Scarcity of megablocks}

A second particularity of $\mathrm{m}_{1}$ is the high proportion of breccias relative to megablocks, which suggests pervasive and relatively uniform fragmentation of the moving mass. This likely resulted from two factors: (i) the relative weakness of the rocks involved, and (ii) the more homogeneous nature of material in $\mathrm{m}_{1}$ compared to that in debris avalanches related to volcanic edifices, which typically comprise very weak pyroclastic deposits or hydrothermally altered material, interbedded with resistant lava flows or domes. As a result, the moving $\mathrm{m}_{1}$ mass was more homogeneously fragmented, producing a high proportion of breccias relative to megablocks (Fig. 12c). The dearth of megablocks in the upper part of $\mathrm{m}_{1}$ would also have contributed to the absence of hummocks. A good illustration of the influence of the mechanical homogeneity of the source material is provided by the Blackhawk landslide, which consists almost exclusively of limestone fragments no more than $20 \mathrm{~cm}$ in size and lacks megablocks (Shreve, 1968).

\section{Interactions of the debris avalanche with the substrate}

A sharp and erosive contact with the substrate, as observed in Feistmantel Valley, has been described for several debris avalanches (Siebe et al., 1992; Schneider and Fisher, 1998; Abbott et al., 2002). Folding of the substrate material has also been reported previously (Siebe et al., 1992; Belousov et al., 1999; Clavero et al., 2002). We propose that these features are likely to be commonly associated with debris avalanches, and reflect intense shearing, compression, and ephemeral dilatation of the substrate. The roles of shearing and compression are clear, but dilatation in response to kinetic energy transfer to a fractured, granulating substrate (Pollet and Schneider, 2004) allows more fluid-like response of substrate materials, and can facilitate folding, or injection of substrate material as clastic dikes. Less common are gradational contacts like those observed on northern Mt Watters, where intact Feather Sandstone progressively grades upwards into matrix-rich sandstone breccias (BX3) that form a discontinuous layer, generally $\leq 10 \mathrm{~m}$ thick but locally up to $80 \mathrm{~m}$ thick, at the base of the debris avalanche deposit (Fig. 12c). The Feather sandstones were brecciated in situ as were those of the Weller Coal Measures, but in many places disruption and mobilization of the sandstones occurred through loss of cohesion between quartz grains. Basal layers of structureless sand and pebbles originating from the substrate have been observed for other debris avalanche deposits (Shreve, 1968; Clavero et al., 2002), although they are normally less than $1 \mathrm{~m}$ thick. The presence of sediments rafted 
within the basal layer of the Parinacota debris avalanche (Clavero et al., 2002) suggests that these layers form by ingestion and fragmentation of substrate blocks, whereas BX3 breccias clearly result from in situ disruption of the substrate. The factors most likely to have resulted in internal disaggregation of the sandstones, rather than fragmentation into blocks, are a low degree of original consolidation/cementation, in part itself the result of the coarse grain size and the good sorting, of the Lower Feather Sandstone. Such rocks can probably be readily transformed into a non-cohesive granular material given a minimal mechanical energy input from the overriding debris avalanche. Grain collisions induced by ground shaking or shearing may ultimately result in dilation and mobilization of this material (e.g. Pollet and Schneider, 2004). Alternatively, sand mobilization might have been related to temporary liquefaction of water-saturated sedimentary rocks due to sudden loading and shaking in relation with the passage of the debris avalanche (Legros, 2002).

In summary, different types of contacts with the substratum in Feistmantel Valley and northern Mt Watters reflect the nature of substrate rocks. Where the rocks were somewhat resistant, shaking and shearing by the debris avalanche resulted in brecciation and deformation of the substrate (Weller Coal Measures in Feistmantel Valley), with fragments of brecciated substrate picked-up by the debris avalanche. In contrast, where the substratum consisted of coarse-grained, poorly indurated sandstones, loading, shaking and shearing by the debris avalanche resulted in loss of cohesion, due to dilation through grain collisions and/or liquefaction, and this ultimately led to mobilization of the Lower Feather on northern Mt Watters.

\section{IMPLICATIONS FOR LARGE IGNEOUS PROVINCES}

To our knowledge, this paper presents the first description of a debris avalanche related to large igneous province magmatism. Considering the enormous volumes of magma emplaced as, or transiting through, dikes or sills during large igneous province formation, large-scale collapse of country rocks are almost certain to be common if steep topographies are present. Steep slopes are likely to be particularly common within large igneous provinces in which tectonic extension precedes or occurs synchronously with volcanism, but may also develop by fluvial incision in situations where there is uplift of an erodible substrate in conjunction with strong runoff. For example, steep walls produced by incremental normal faulting over time encourage wallrock collapse, and magmatic intrusions can provide a trigger for outsized events. At central Allan Hills, the sparsely basalt-bearing debris avalanche deposits constitute the oldest record of mafic Jurassic volcanic activity. The occurrence of debris avalanches during the early stages of continental large igneous province formation could be relatively common, but progressive flooding of the landscape by lava flows and volcaniclastic deposits would prevent subsequent collapse and hinder identification of the earliest deposits in provinces with lesser (or significantly greater) degrees of erosion than the Ferrar. We infer that large igneous provinces having significant steeply sloping topography prior to eruptions should also have common debrisavalanche deposits. This is because magma is delivered to the land surface at numerous sites in a large igneous province, yielding a high probability that feeders to the surface will pass near unstable slopes susceptible to collapse.

In conclusion, debris avalanches appear to be one of the variety of phenomena that can accompany large igneous province volcanism, despite the common absence of large central volcanic edifices. The $\mathrm{m}_{1}$ case suggests that in the context of large igneous province volcanism, destabilization of the substratum by intruding magmas results in lateral collapse and formation of debris avalanches providing the preexistence of steep topographies.

\section{ACKNOWLEDGMENTS}

Our work at Allan Hills was supported by Antarctica New Zealand, the University of Otago, and a $\mathrm{PhD}$ scholarship to Ross from the Fonds de recherche sur la nature et les technologies (Quebec, Canada). O. Reubi thanks J. Hernandez for hosting him at the Université de Lausanne during final revision of the manuscript. We thank L. Siebert for discussions on debris avalanches, A. Belousov and R. Norris for reading the text prior to submission, plus D. Jerram, an anonymous reviewer and associate editor N. Riggs for constructive comments on the submitted typescript.

\section{REFERENCES}

Abbott, P., Kerr, D., Borron, S. E., Washburn, J. L., and Rightmer, D. A., 2002, Neogene sturzstrom deposits, Split Mountain area, Anza-Borrego Desert State Park, California, in Evans, S. G., and DeGraff, J. V., eds., Catastrophic landslides: Effects, Occurrence, and mechanisms: Geological Society of America, Reviews in Engineering Geology 15, p. 379-400.

Ballance, P. F., 1977, The Beacon Supergroup in the Allan Hills, central Victoria Land, Antarctica: New Zealand Journal of Geology and Geophysics, v. 20, p. 1003-1016.

Ballance, P. F., and Watters, W. A., 1971, The Mawson Diamictite and the Carapace Sandstone, formations of the Ferrar Group at Allan Hills and Carapace Nunatak, Victoria Land, Antarctica: New Zealand Journal of Geology and Geophysics, v. 14, p. 512-527.

Barrett, P. J., 1991, The Devonian to Jurassic Beacon Supergroup of the Transantarctic Mountains and correlatives in other parts of Antarctica, in Tingey, R. J., ed., The Geology of Antarctica: Oxford, Oxford University Press, p. 120-152.

Barrett, P. J., and Kohn, B. P., 1975, Changing sediment transport directions from Devonian to Triassic in the Beacon Super-group of South Victoria Land, Antarctica, in Campbell, K. S. W., ed., Gondwana Geology: Canberra, A.N.U. Press, p. 15-35.

Belousov, A., Belousova, M., and Voight, B., 1999, Multiple edifice failures, debris avalanches and associated eruptions in the Holocene history of Shiveluch volcano, Kamchatka, Russia: Bulletin of Volcanology, v. 61, p. 324-342.

Bornholdt, C., 2001, The Mawson Formation of the Watters Peak area, Allan Hills, Central Victoria Land, Antarctica [B.Sc. Honors thesis]: Wellington, New Zealand, Victoria University of Wellington, $98 \mathrm{p}$. 
Borns, H. W., and Hall, B. A., 1969, Mawson "Tillite" in Antarctica: Preliminary report of a volcanic deposit of Jurassic age: Science, v. 166, p. 870-872.

Bradshaw, M. A., 1987, Additional field interpretation of the Jurassic sequence at Carapace Nunatak and Coombs Hills, south Victoria Land, Antarctica: New Zealand Journal of Geology and Geophysics, v. 30, p. 37-49.

Bradshaw, M. A., 1991, The Devonian Pacific margin of Antarctica, in Thomson, M. R. A., Crame, J. A., and Thomson, J. W., eds., Geological Evolution of Antarctica: Cambridge, Cambridge University Press, p. 193-197.

Brauns, C. M., Hergt, J. M., Woodhead, J. D., and Maas, R., 2000, Os isotopes and the origin of the Tasmanian Dolerites: Journal of Petrology, v. 41, p. 905-918.

Clavero, J., Sparks, R., Huppert, H., and Dade, W., 2002, Geological constraints on the emplacement mechanism of the Parinacota debris avalanche, northern Chile: Bulletin of Volcanology, v. 64, p. 40-54.

Collinson, J. W., Pennington, D. C., and Kemp, N. R., 1983, Sedimentary petrology of Permian-Triassic fluvial rocks in the Allan Hills, central Victoria Land: Antarctic Journal of the United States, v. 18, p. 20-22.

Collinson, J. W., Isbell, J. L., Elliot, D. H., Miller, M. F., and Miller, J. M. G., 1994, Permian-Triassic Transantarctic basin, in Veevers, J. J., and Powell, C. M., eds., PermianTriassic Pangean Basins and Foldbelts Along the Panthalassan Margin of Gondwanaland: Geological Society of America Memoir 184, p. 173-222.

Day, S. J., 1996, Hydrothermal pore fluid pressure and stability of porous, permeable volcanoes, in McGuire, W. J., Jones, A. P., and Neuberg, J., eds., Volcano Instability on the Earth and others planets: Geological Society Special Publication 110, p. 77-93

Elliot, D. H., 1972, Major oxide chemistry of the Kirkpatrick Basalt, Central Transantarctic Mountains, in Adie, R. J., ed., Antarctic Geology and Geophysics: Oslo, Universitetsforlagets, p. 413-418.

Elliot, D. H., 1992, Jurassic magmatism and tectonism associated with Gondwanaland break-up: an Antarctic perspective, in Storey, B. C., Alabaster, T., and Pankhurst, R. J., eds., Magmatism and the Causes of Continental Break-up: Geological Society Special Publication 68, p. 165-184.

Elliot, D. H., 1996, The Hanson Formation: a new stratigraphical unit in the Transantarctic Mountains, Antarctica: Antarctic Science, v. 8, p. 389-394.

Elliot, D. H., 2000, Stratigraphy of Jurassic pyroclastic rocks in the Transantarctic Mountains: Journal of African Earth Sciences, v. 31, p. 77-89.

Elliot, D. H., 2002, Paleovolcanological setting of the Mawson Formation: evidence from the Prince Albert Mountains, Victoria Land, in Gamble, J. A., Skinner, D. N. B., and Henrys, R., eds., Antarctica at the close of a millenium: Royal Society of New Zealand Bulletin 35, p. 185-192.

Elliot, D. H., and Larsen, D., 1993, Mesozoic volcanism in the central Transantarctic Mountains, Antarctica: Depositional environment and tectonic setting, in Findlay, R. H., Unrug, R., Banks, M. R., and Veerers, J. J., eds., Assembly, evolution and dispersal; proceedings of the Gondwana Eight symposium: Rotterdam, Balkema, p. 397-410.

Elliot, D. H., and Hanson, R. E., 2001, Origin of widespread, exceptionally thick basaltic phreatomagmatism tuff breccia in the Middle Jurassic Prebble and Mawson Formations, Antarctica: Journal of Volcanology and Geothermal Research, v. 111, p. 183-201.

Elliot, D. H., Haban, M. A., and Siders, M. A., 1986, The Exposure Hill Formation, Mesa Range, in Stump, E., ed., Geological Investigations in Northern Victoria Land:
American Geophysical Union, Antarctic Research Series 46, p. 267-278.

Elliot, D. H., Fleming, T. H., Kyle, P. R., and Foland, K. A., 1999, Long-distance transport of magmas in the Jurassic Ferrar Large Igneous Province, Antarctica: Earth and Planetary Science Letters, v. 167, p. 89-104.

Elliot, D. H., Fortner, T., and Grimes, C. B., 2004, BeaconMawson field relations at Allan and Coombs Hills, south Victoria Land, Proceedings of the Ninth International Symposium on Antarctic Earth Sciences: Postdam, Germany.

Elsworth, D., and Voight, B., 1996, Evolution of volcano flank instability triggered by dike intrusion, in McGuire, W. J., Jones, A. P., and Neuberg, J., eds., Volcano Instability on Earth and Other Planets: Geological Society Special Publication 110, p. 45-53.

Fleming, T. H., Elliot, D. H., Jones, L. M., Bowman, J. R., and Siders, M. A., 1992, Chemical and isotopic variations in an iron-rich flow from the Kirkpatrick Basalt, north Victoria Land, Antarctica: implications for lowtemperature alteration: Contributions to Mineralogy and Petrology, v. 111, p. 440-457.

Francis, P. W., and Wells, G. L., 1988, Landsat Thematic Mapper observations of debris avalanche deposits in the Central Andes: Bulletin of Volcanology, v. 50, p. 258278.

Glicken, H., 1991, Sedimentary architecture of large volcanic debris avalanches, in Fisher, R. V., and Smith, G. A., eds., Sedimentation in Volcanic Settings: Society of Economic Paleontologists and Mineralogists Special Publication 45, p. $99-105$.

Grapes, R. H., Reid, D. L., and McPherson, J. G., 1974, Shallow dolerite intrusion and phreatic eruption in the Allan Hills region, Antarctica: New Zealand Journal of Geology and Geophysics, v. 17, p. 563-577.

Grindley, G. W., 1963, The geology of the Queen Alexandra Range, Beardmore Glacier, Ross Dependency, Antarctica; with notes on the correlation of Gondwana sequences: New Zealand Journal of Geology and Geophysics, v. 6, p. 307-347.

Gunn, B. M., and Warren, G., 1962, Geology of Victoria Land between the Mawson and Murlock Glaciers, Antarctica, New Zealand Geological Society Bulletin 71, 157 p.

Hanson, R. E., and Elliot, D. H., 1996, Rift-related Jurassic phreatomagmatism in the central Transantarctic Mountains: precursory stage to flood-basalt effusion: Bulletin of Volcanology, v. 58, p. 327-347.

Heimann, A., Fleming, T. H., Elliot, D. H., and Foland, K. A., 1994, A short interval of Jurassic continental flood basalt volcanism in Antarctica as demonstrated by ${ }^{40} \mathrm{Ar} /{ }^{39} \mathrm{Ar}$ geochronology: Earth and Planetary Science Letters, v. 121, p. 19-41.

Hergt, J. M., and Brauns, C. M., 2001, On the origin of Tasmanian Dolerites: Australian Journal of Earth Sciences, v. 48, p. 543-549.

Hsü, K. J., 1978, Albert Heim: observations on landslides and relevance to modern interpretations, in Voight, B., ed., Rockslides and Avalanches, 1: Natural Phenomena: Amsterdam, Elsevier, p. 70-93.

Jerram, D. A., 2002, Volcanology and facies architecture of flood basalts, in Menzies, M. A., Klemperer, S. L., Ebinger, C. J., and Baker, J., eds., Volcanic Rifted Margins: Geological Society of America Special Paper 362, p. 121-135.

Korsch, R. J., 1984, The structure of Shapeless Mountain, Antarctica, and its relation to Jurassic igneous activity: New Zealand Journal of Geology and Geophysics, v. 27, p. 487-504.

Legros, F., 2002, The mobility of long-runout landslides. Engineering Geology, v. 63, p. 301-331. 
Lockett, G. M., 2003, Landslide and debris flow deposits at the margin of a large vent complex, Mawson Formation, Allan Hills, southern Victoria Land, Antarctica. [M.S. thesis]: Dunedin, New Zealand, University of Otago.

Lockett, G. M., and White, J. D., 2002, Sandstone landslides associated with explosive volcanism, Mawson Formation, Ferrar Supergroup, Allan Hills, Antarctica [abstract]: Eos (Transactions, American Geophysical Union), Western Pacific Geophysics Meeting Supplement, abstract SE51B07.

Masson, D. G., Watts, A. B., Gee, M. J. R., Urgeles, R., Mitchell, N. C., Le Bas, T. P., and Canals, M., 2002, Slope failures on the flanks of the western Canary Islands: Earth-Science Reviews, v. 57, p. 1-35.

McClintock, M. K., 2001, Phreatomagmatism at Coombs Hills, Antarctica - Magma-water super-volcanism in a wet, failed rift [M.S. thesis]: Dunedin, New Zealand, University of Otago, $189 \mathrm{p}$.

McClintock, M. K., and White, J. D. L., 2005, Large-volume phreatomagmatic vent complex at Coombs Hills, Antarctica records wet, explosive initiation of flood basalt volcanism in the Ferrar LIP: Bulletin of Volcanology. (in press)

McGuire, W. J., 1996, Volcano instability: a review of contemporary themes, in McGuire, W. J., Jones, A. P., and Neuberg, J., eds., Volcano Instability on Earth and Other Planets: Geological Society Special Publication 110, p. 1-23.

Mortimer, N., Parkinson, D., Raine, J. I., Adams, C. J., Graham, I. J., Oliver, P. J., and Palmer, K., 1995, Ferrar magmatic province rocks discovered in New Zealand: Implications for Mesozoic Gondwana geology: Geology [Boulder], v. 23, p. 185-188.

Naranjo, N. A., and Francis, P. W., 1987, High velocity debris avalanche at Lastarria volcano in the north Chilean Andes: Bulletin of Volcanology, v. 49, p. 509-514.

Pollet, N., and Schneider, J.-L. M., 2004, Dynamic disintegration processes accompanying transport of the Holocene Flims sturzstrom (Swiss Alps): Earth and Planetary Science Letters, v. 221, p. 433-448.

Reubi, O., and Hernandez, J., 2000, Volcanic debris avalanche deposits of the upper Maronne valley (Cantal Volcano, France): evidence for contrasted formation and transport mechanisms: Journal of Volcanology and Geothermal Research, v. 102, p. 271-286.

Ross, P.-S., 2005, Volcanology of the Mawson Formation at Coombs and Allan Hills, South Victoria Land, Antarctica [PhD Thesis]: Dunedin, New Zealand, University of Otago, $400 \mathrm{p}$.

Ross, P.-S., and White, J.D.L., 2005, Mafic, large-volume, pyroclastic density current deposits from phreatomagmatic eruptions in the Ferrar large igneous province, Antarctica: Journal of Geology (in revision)

Ross, P.-S., and White, J. D. L., submitted, Debris-filled volcanic vent structures in a phreatomagmatic complex at
Coombs Hills, Ferrar large igneous province, Antarctica: Journal of Volcanology and Geothermal Research.

Ross, P.-S., Ukstins Peate, I., McClintock, M. K., Xu, Y. G., Skilling, I. P., White, J. D. L., and Houghton, B. F., 2005, Mafic volcaniclastic deposits in flood basalt provinces: a review: Journal of Volcanology and Geothermal Research, doi:10.1016/j.jvolgeores.2005.02.003

Schneider, J. L., and Fisher, R. V., 1998, Transport and emplacement mechanisms of large volcanic debris avalanches: evidence from the northwest sector of Cantal Volcano (France): Journal of Volcanology and Geothermal Research, v. 83, p. 141-165.

Schneider, J. L., Wassmer, P., and Ledesert, B., 1999, Internal fabric of sturzstrom deposits in Flims (Swiss Alps); characteristics and implications for transport mechanisms: Comptes Rendus de l'Académie des Sciences, v. 328, p. 607-613.

Shreve, R. L., 1968, The Blackhawk landslide: Geological Society of America Special Paper 108, 47 p.

Siebe, C., Komorowski, J.-C., and Sheridan, M. F., 1992, Morphology and emplacement of unusual debrisavalanche deposit at Jocotilan volcano: Bulletin of Volcanology, v. 54, p. 573-589.

Siebert, L., 1984, Large volcanic debris avalanches: Characteristics of source areas, deposits, and associated eruptions: Journal of Volcanology and Geothermal Research, v. 22, p. 163-197.

Ui, T., 1983, Volcanic dry avalanche deposits: Identification and comparison with nonvolcanic debris stream deposits: Journal of Volcanology and Geothermal Research, v. 18, p. 135-150.

Ui, T., Takarada, S., and Yoshimoto, M., 2000, Debris avalanches, in Sigurdsson, H., Houghton, B., McNutt, S. R., Rymer, H., and Stix, J., eds., Encyclopedia of Volcanoes: London, Academic Press, p. 617-626.

Ukstins Peate, I., Larsen, M., and Lesher, C. E., 2003, The transition from sedimentation to flood volcanism in the Kangerlussuaq Basin, East Greenland: basaltic pyroclastic volcanism during initial Palaeogene continental break-up: Journal of the Geological Society [London], v. 160, p. 759-772.

Voight, B., Janda, R. J., Glicken, H., and Douglas, P. M., 1983, Nature and mechanics of the Mount St. Helens rockslideavalanche of 18 May 1980: Geotechnique, v. 33, p. 243273.

Voight, B., Janda, R. J., Glicken, H., and Douglas, P. M, 1985, Reply to discussion: Nature and mechanics of the Mount St. Helens rockslide-avalanche of 18 May 1980: Geotechnique, v. 35, p. 357-368.

White, J. D. L., and McClintock, M. K., 2001, Immense vent complex marks flood-basalt eruption in a wet, failed rift: Coombs Hills, Antarctica: Geology [Boulder], v. 29, p. 935-938.

\section{FIGURES}

1. (a) Map showing the distribution of the Beacon Supergroup, Ferrar Dolerite, and Kirkpatrick Basalt in the Transantarctic Mountains (TAM). Mafic volcaniclastic deposits, including the Mawson Formation, are found underlying the Kirkpatrick Basalt in North Victoria Land (NVL), South Victoria Land (SVL) and the Central Transantarctic Mountains (CTM). Redrawn after Hanson and Elliot (1996). (b) Distribution of the Mawson Formation and correlatives (shaded, after Grapes et al., 1974, except for Coombs Hills, modified from McClintock, 2001) in the Coombs Hills-Allan Hills area of SVL. Elevations contours (ice-covered areas only) are in meters above sea level.

2. Geological maps and sections of central Allan Hills. Victoria Group inter-formation contacts after Bornholdt (2001); Sirius Group distribution after Atkins et al. (2002); new $50 \mathrm{~m}$ contours (dashed lines) based on 562 GPS spot heights (not shown); Beacon-Mawson, $\mathrm{m}_{1}-\mathrm{m}_{2}$ and deformed-undeformed Weller contacts based on new mapping. (a) Map of 
the whole field area; (b) zoom on the better-constrained part of the debris avalanche showing the distribution of the different breccia types (labels BX1 to BX4) and the location of some megablocks (filled lozenges). "TB ${ }_{j}{ }^{\prime \prime}$ on section BB' stands for poorly sorted, basalt-rich tuff-breccias cross-cutting $\mathrm{m}_{1}$ and "LT $\mathrm{a}_{\mathrm{a}}$ represents steep to sub-vertical zones poorly sorted, Beacon-rich lapilli-tuffs with abrupt contacts and elliptical outlines in map view (also invading $\mathrm{m}_{1}$ ). "Basalt plugs" are post- $\mathrm{m}_{1}$ intrusions of coherent basalt, not to be confused with rootless basaltic bodies in $\mathrm{m}_{1}$ discussed with the other 'megablocks'.

3. View looking northeast of Feistmantel Valley (foreground), the northeast arm of Allan Hills including Roscollyn Tor, and western Mt Watters. The contacts between $\mathrm{m}_{1}$ and the substratum, plus the approximate $\mathrm{m}_{1}-\mathrm{m}_{2}$ contact on $\mathrm{Mt}$ Watters, are also annotated.

4. Photographs illustrating megablocks in the $\mathrm{m}_{1}$ debris avalanche at central Allan Hills. (a) A sandstone megablock in Feistmantel Valley, just above the contact with the Weller Coal Measures (WCM). Backpack for scale. (b) Interior of a fragmented, laminated sandstone megablock showing a jigsaw-fit texture. (c) Fragmented border of a coal-bearing sandstone-to-siltstone megablock. (d) Partially deformed sandstone megablock, with preserved original bedding, hosted by BX2-type breccias. Arrows points to hammer for scale. (e) Zone of accumulation of megablocks on northern Mt Watters, showing a tabular sandstone megablock (marked S) and a basalt megablock (B) surrounded by BX1-type breccias. Person for scale. (f) Flame structure formed by a deformed yellow sandstone megablock (dashed outline, marked Y) within the surrounding BX1-type breccias on northern Mt Watters.

5. Schematic section through $\mathrm{m}_{1}$ on northern Mt Watters, in the thickest part of the avalanche, showing the distribution of breccia types and megablocks. For location see figure $2 \mathrm{a}$.

6. Photographs illustrating breccia types in the $\mathrm{m}_{1}$ debris avalanche at central Allan Hills. (a) Typical BX1. (b) BX2 with somewhat more fine-grained sedimentary fragments (dark) than on average. (c) Typical BX3. (d) Typical BX4, showing the net used for clast counting (nodes on the net are spaced by $10 \mathrm{~cm}$ in both directions).

7. Grain size and composition of fragments in matrix-supported Mawson breccias from Feismantel Valley, based on field clast counts. Pie-diagrams show the average values of $n$ counts spread over the entire valley. In each case, 100 clasts were counted in $1 \mathrm{~m}^{2}$ using a grid with a $10 \mathrm{~cm}$ spacing. Left-hand side diagrams represent the proportions of material of different grain size. Right-hand side diagrams show the proportions of fragment types (clasts $\geq 2 \mathrm{~mm}$ only, excluding quartz granules). 'Beacon sst' stands for Beacon sandstone and 'Other Beacon' fragments include siltstone, carbonaceous mudstone, and coal.

8. Photograph and line drawing of a $5 \mathrm{~m}$-high vertical face oriented approximately NE-SW in Feistmantel Valley, showing the contact relationships between $\mathrm{m}_{1}$ and the underlying Weller Coal Measures (WCM). Here $\mathrm{m}_{1}$ consists of matrix-supported breccia (sandstone fragments in a sandy matrix), which overlies the disturbed WCM with a relatively sharp contact, undulating but dipping gently towards the northeast. The coal and mudstone horizons are in their original stratigraphic position but are brecciated in situ (sub-horizontal lines in the lower part of the mudstone horizon show remnants of the original bedding), presumably because of the emplacement of $\mathrm{m}_{1}$. Numerous coal fragments were eroded and entrained by the debris avalanche, indicating transport towards the right in the photograph (i.e., at least a component of the transport vector is to the NE).

9. Photograph and line drawing of a fold in the Weller Coal Measures (WCM) in Feistmantel Valley, just below the contact with the debris avalanche (here BX4, barely visible in the top-left corner). See text for explanation.

10. Deformation of the substratum (Lower Feather Sandstone) on northern Mt Watters. (a) Vertical face showing in situ brecciated sandstones. Original bedding is marked by wavy horizons of variable grain size. Fragments have not moved by more than a few centimeters to decimeters. (b) Vertical face showing brecciation and block tilting in siltstone/fine sandstone interbeds. Such breccias grade upwards into matrix-supported BX3 breccias where fragments have moved substantially.

11. Stereograms (lower hemisphere, equal area projection) of the long axis (dip, dip direction) of tilted fragments in deformed Lower Feather rocks just below the base of $\mathrm{m}_{1}$ on northern Mt Watters. See text for interpretation.

12. Schematic representation of the inferred sequence of events to illustrate the origin of member $m_{1}$ of the Mawson Formation at central Allan Hills. (a) Hypothetical configuration of the source area of the debris avalanche, showing a steep slope in the Beacon sedimentary sequence due to Jurassic normal faulting, with arrival of Ferrar intrusions. (b) Initial formation of the megablocks in the moving mass, and beginning of in situ brecciation in the substrate. The basaltic intrusions are still hot and plastic. (c) Situation after the sedimentary megablocks formed in (b) have been brecciated extensively. The basaltic intrusions are now more dispersed, but still form globular megablocks with haloes of BX1-type breccia enriched in basaltic clasts. The in situ brecciated substrate now grades into a thicker "layer" of BX3-type breccia, which locally can be mobilized up to $100 \mathrm{~m}$ upwards into the debris avalanche. The cartoons were made specifically to explain the deposits on northern Mt Watters, rather than those of Feistmantel Valley. 
a

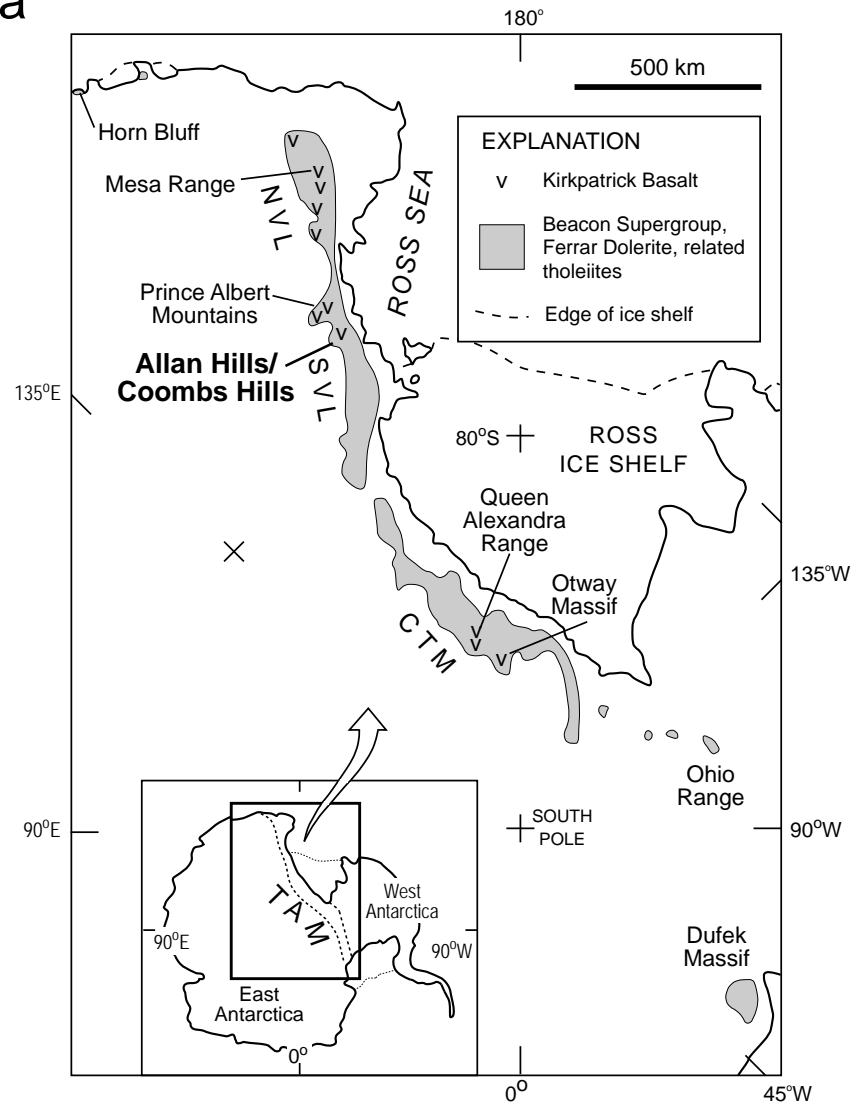

b

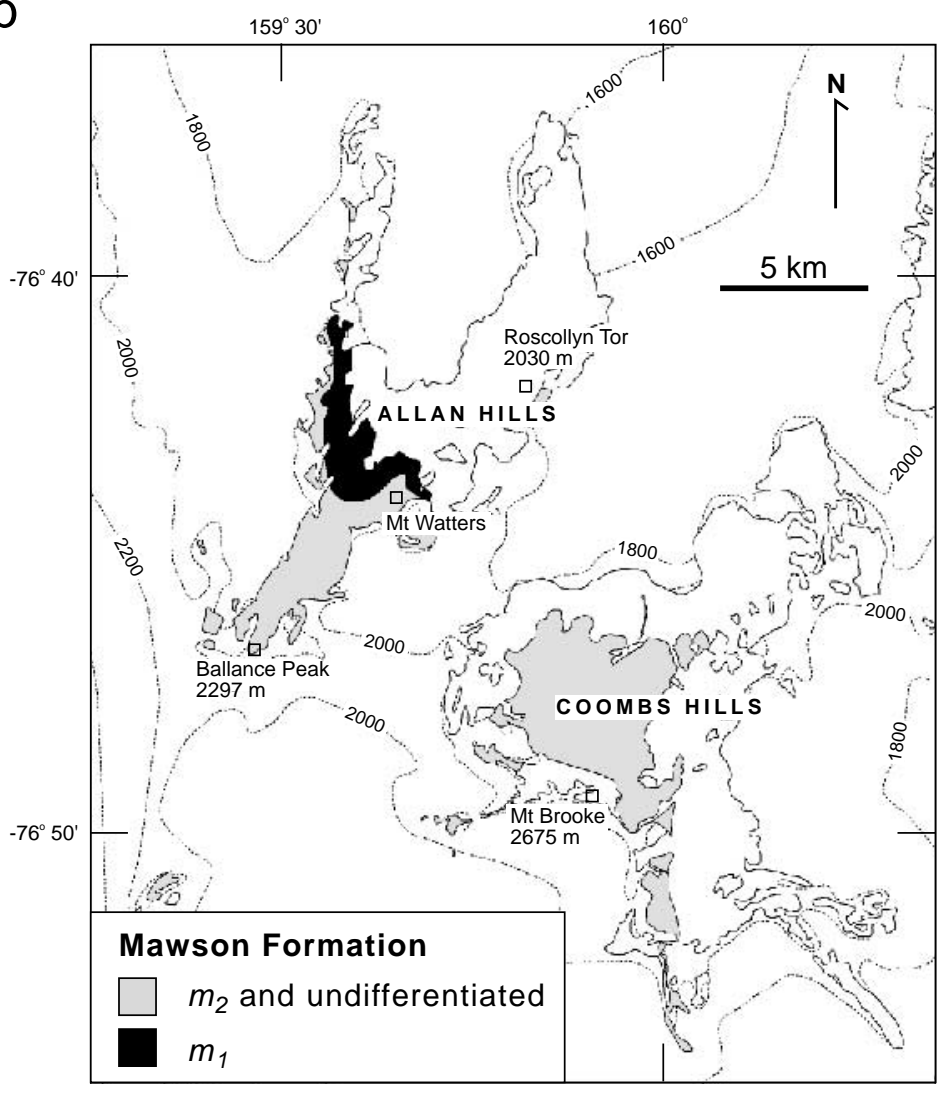

REUBI ET AL, FIG. 1 
a

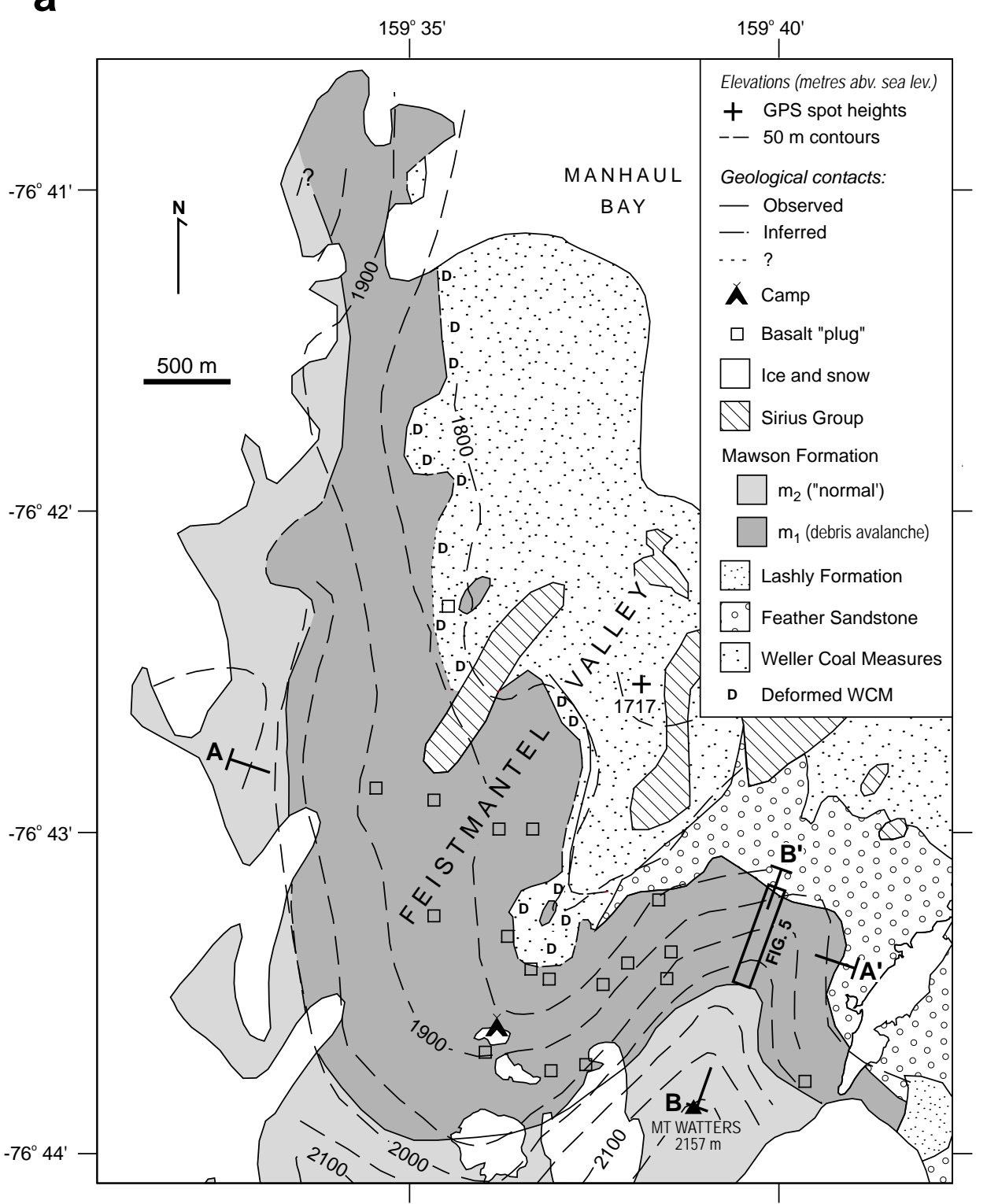

b
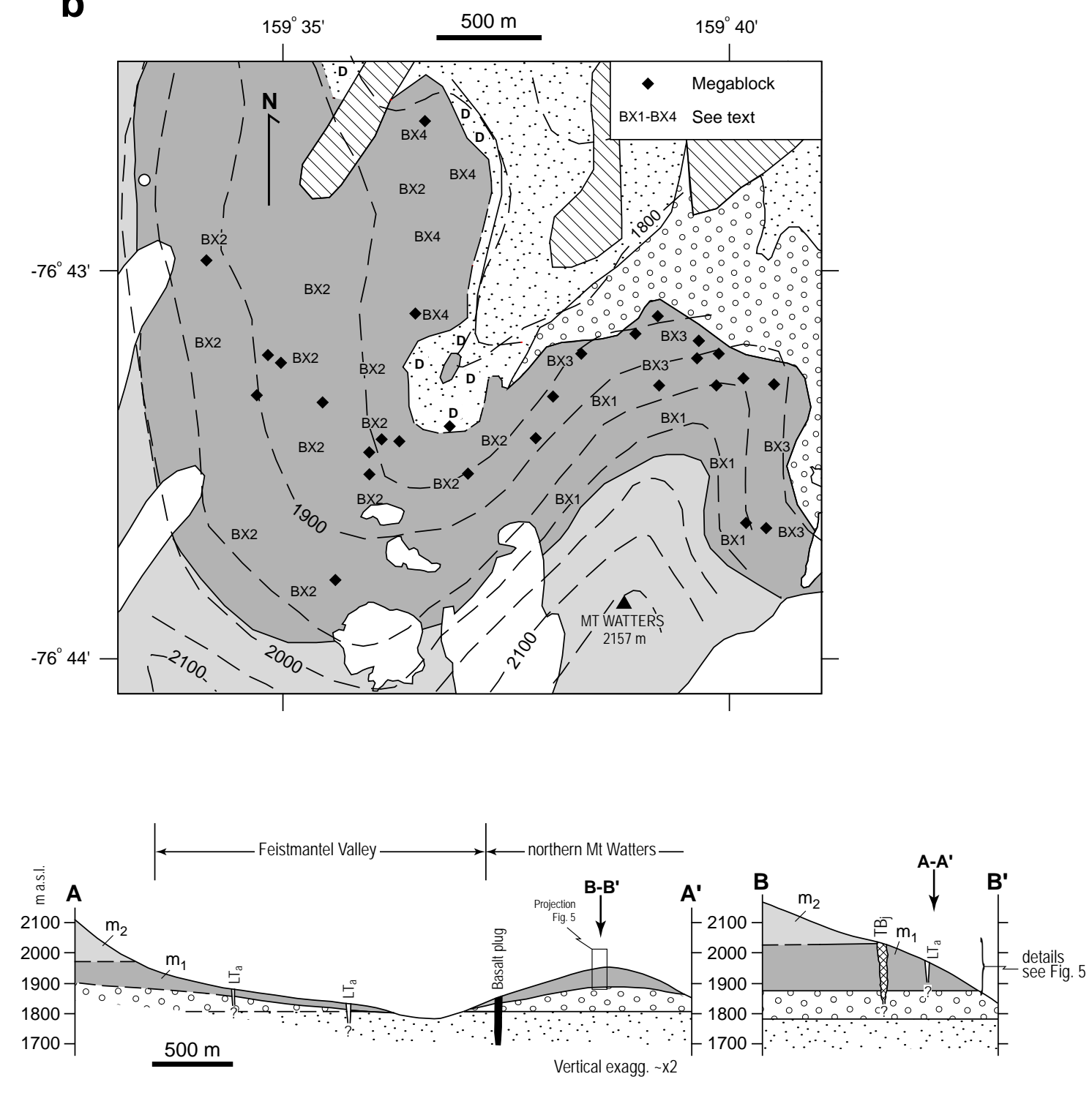


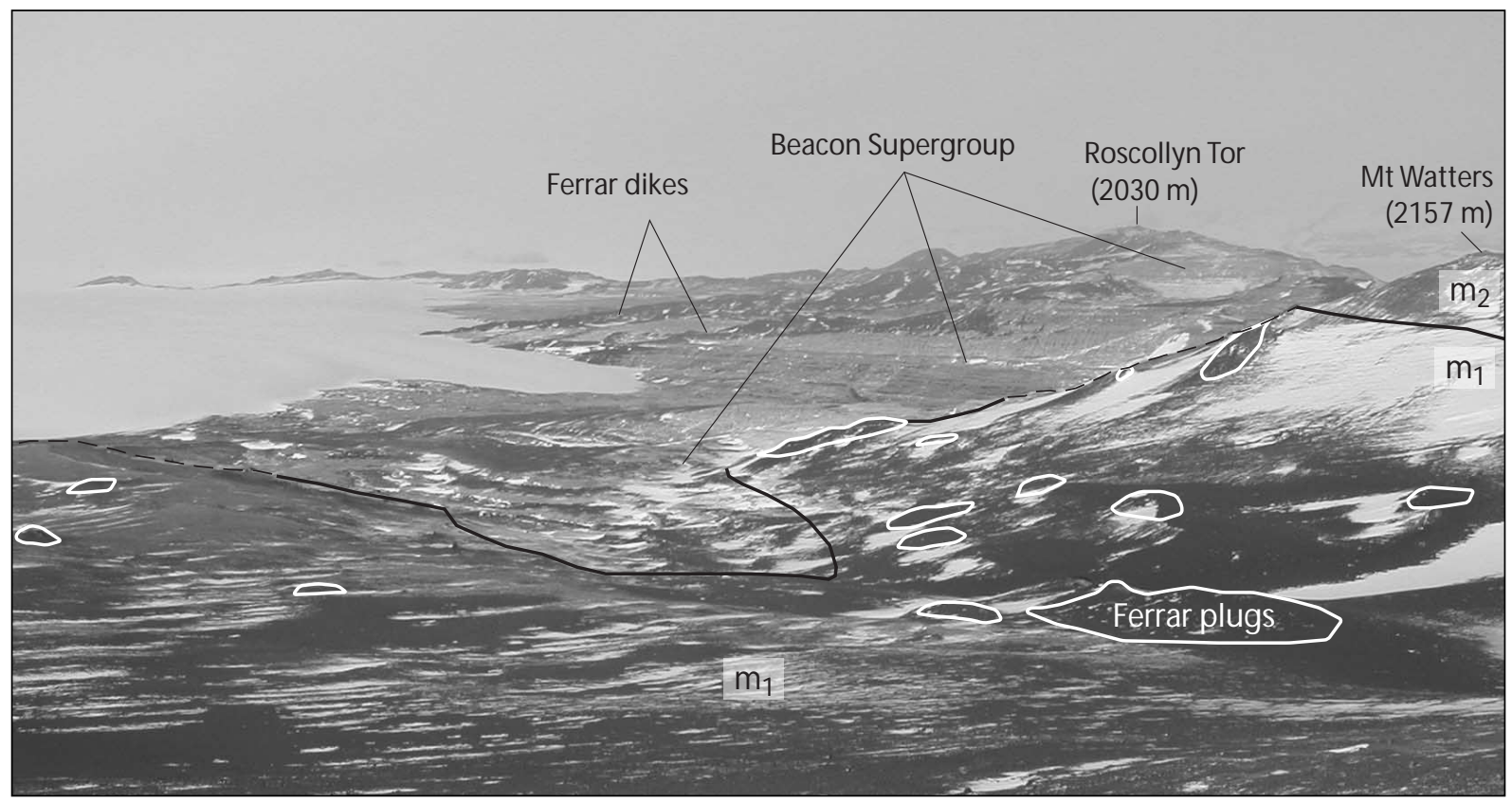

REUBI ET AL., FIG. 3 

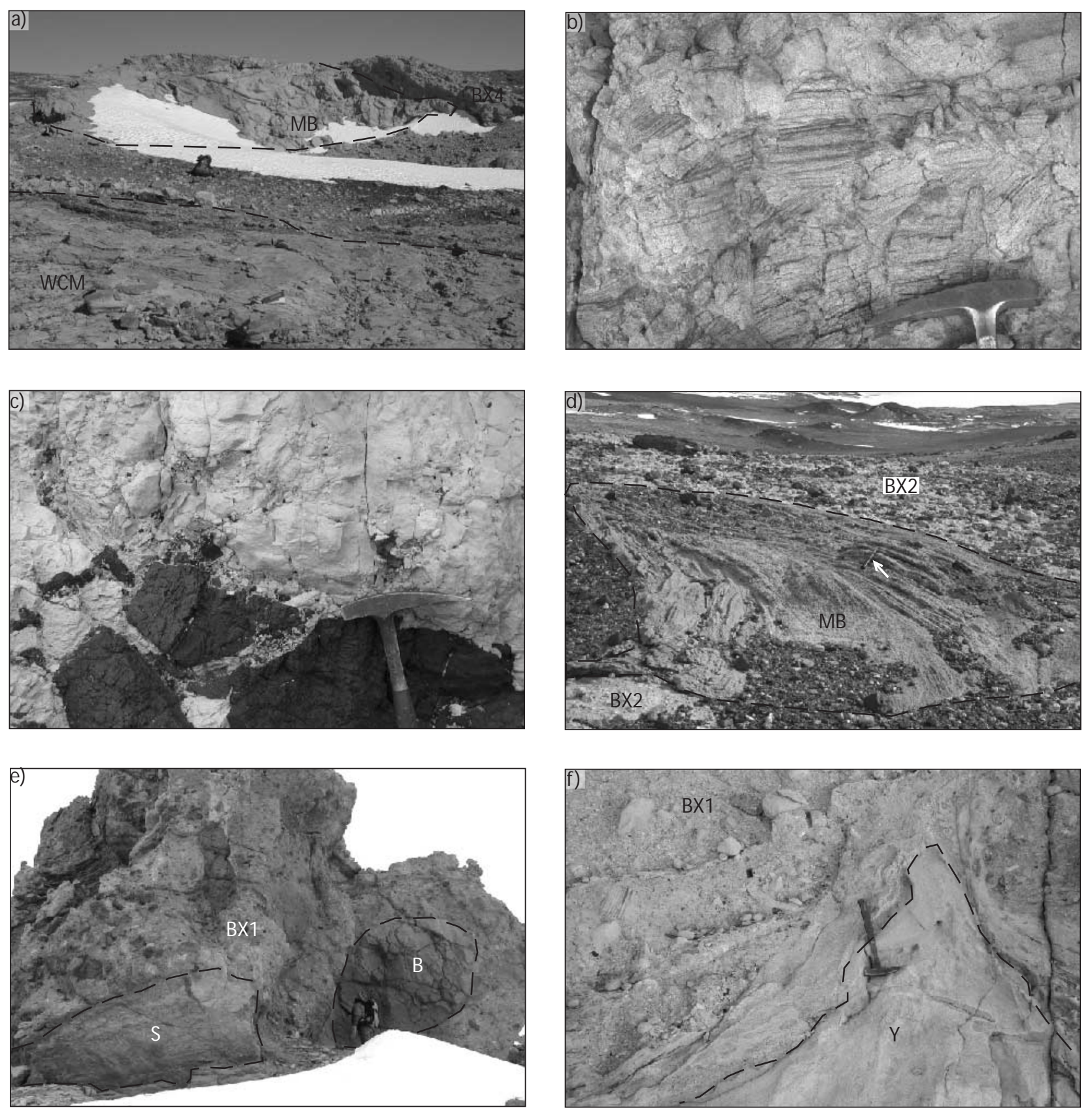

REUBI ET AL., Fig. 4 


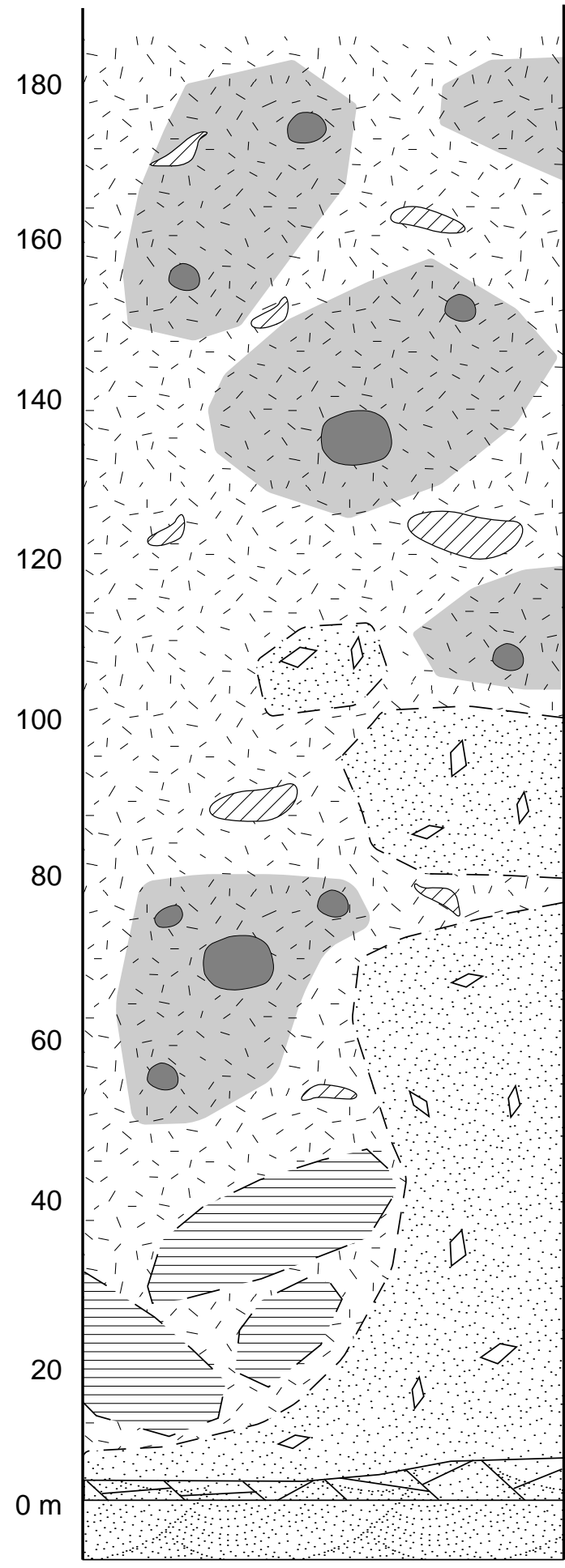

\section{MEGABLOCKS}

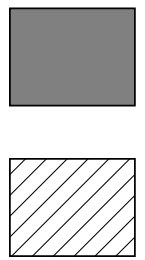

Globular basalt

Yellow sandstone

(Lashly Formation)

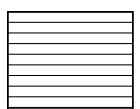

Interbedded mudstone to sandstone (Lashly Formation)

\section{SANDSTONE BRECCIAS}

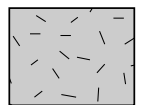

Gray breccia with basalt fragments (BX1)

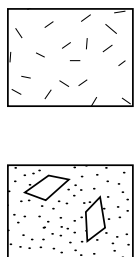

Gray breccia (BX1)

White breccia (BX3)

(mobilized Lower Feather Sandstone)

IN SITU LOWER FEATHER SANDSTONE

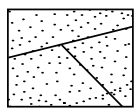

Brecciated sandstone

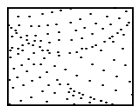

Cross-bedded sandstone

REUBI ET AL., FIG. 5 

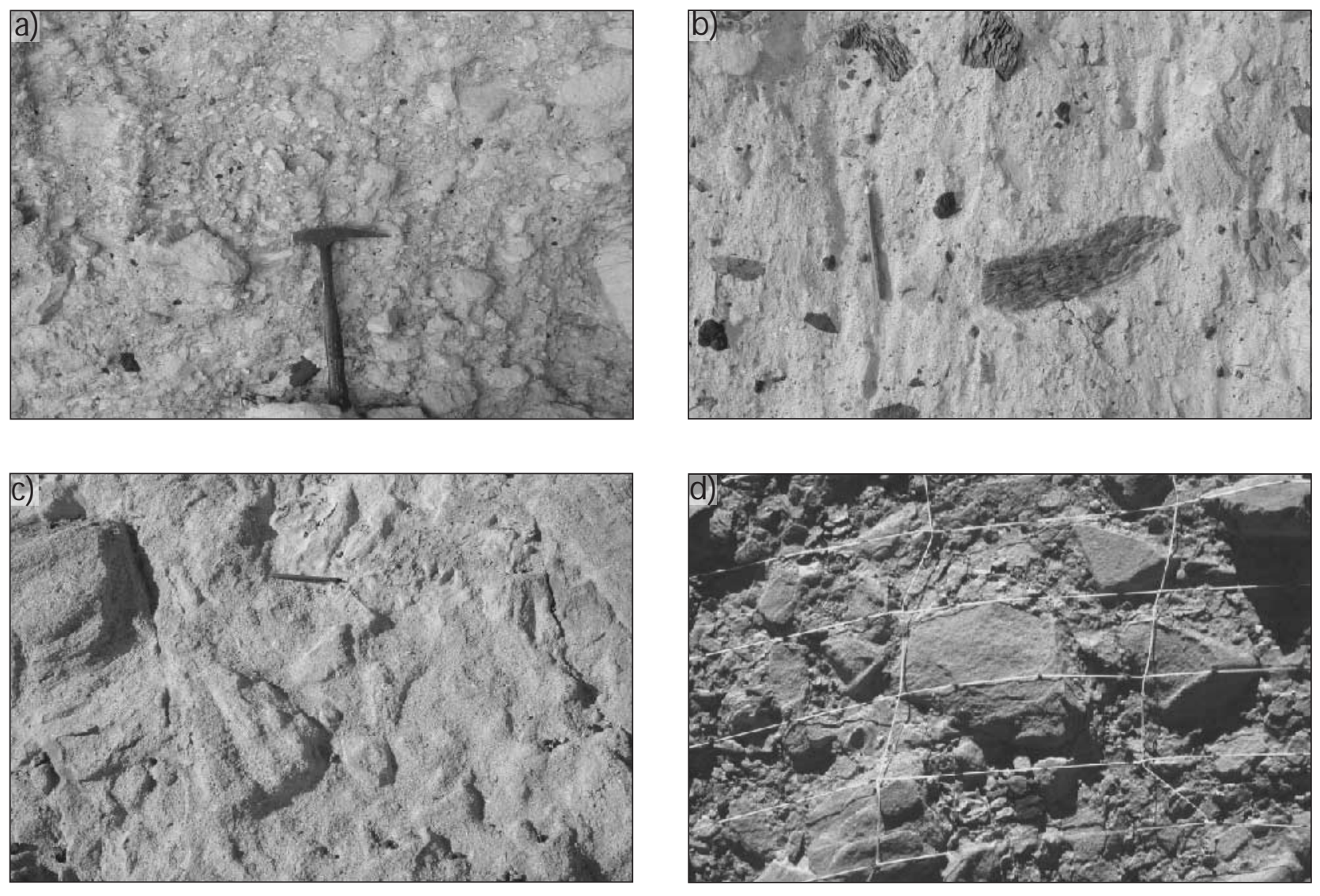

REUBI ET AL., FIG. 6 

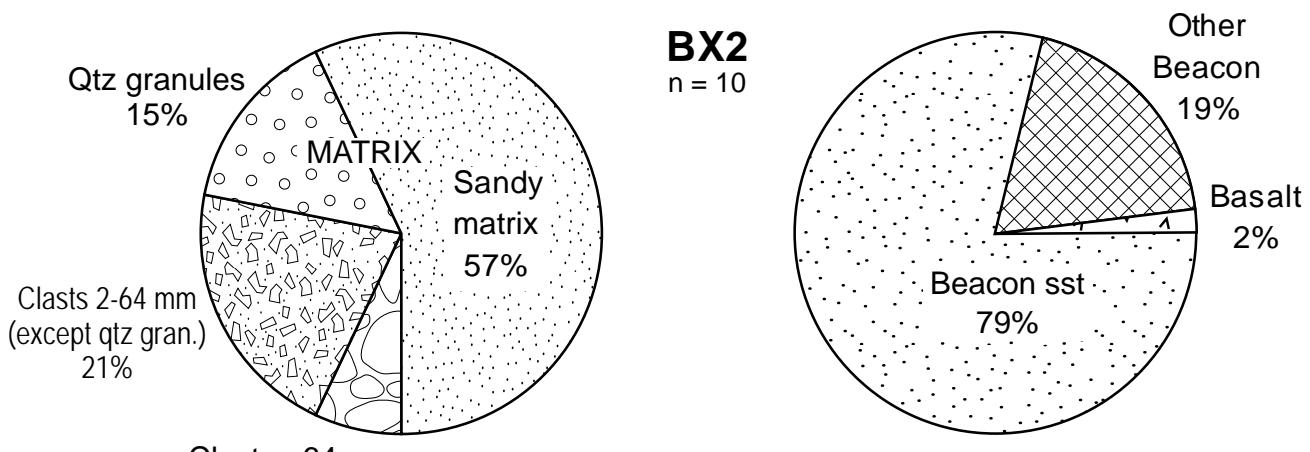

Clasts $>64 \mathrm{~mm}$

$7 \%$

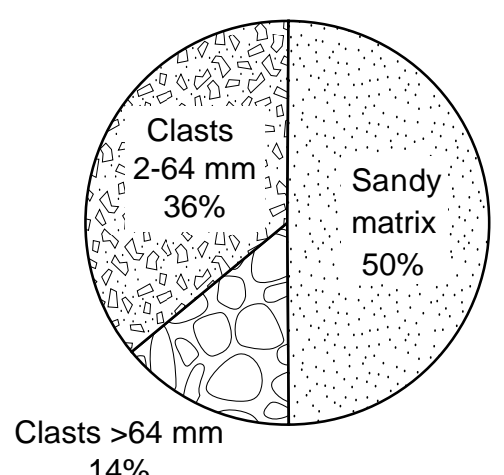

BX4

$\mathrm{n}=6$

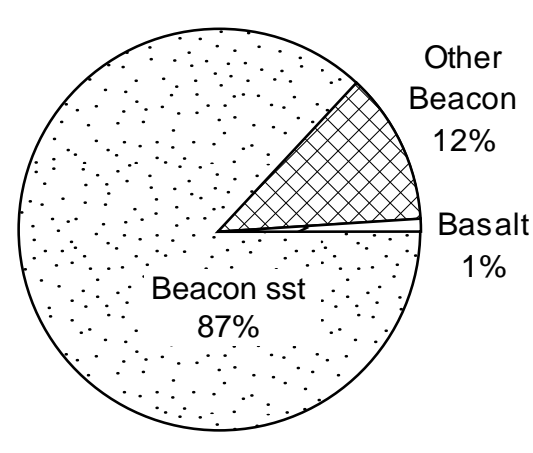

$14 \%$

REUBI ET AL., FIG. 7 

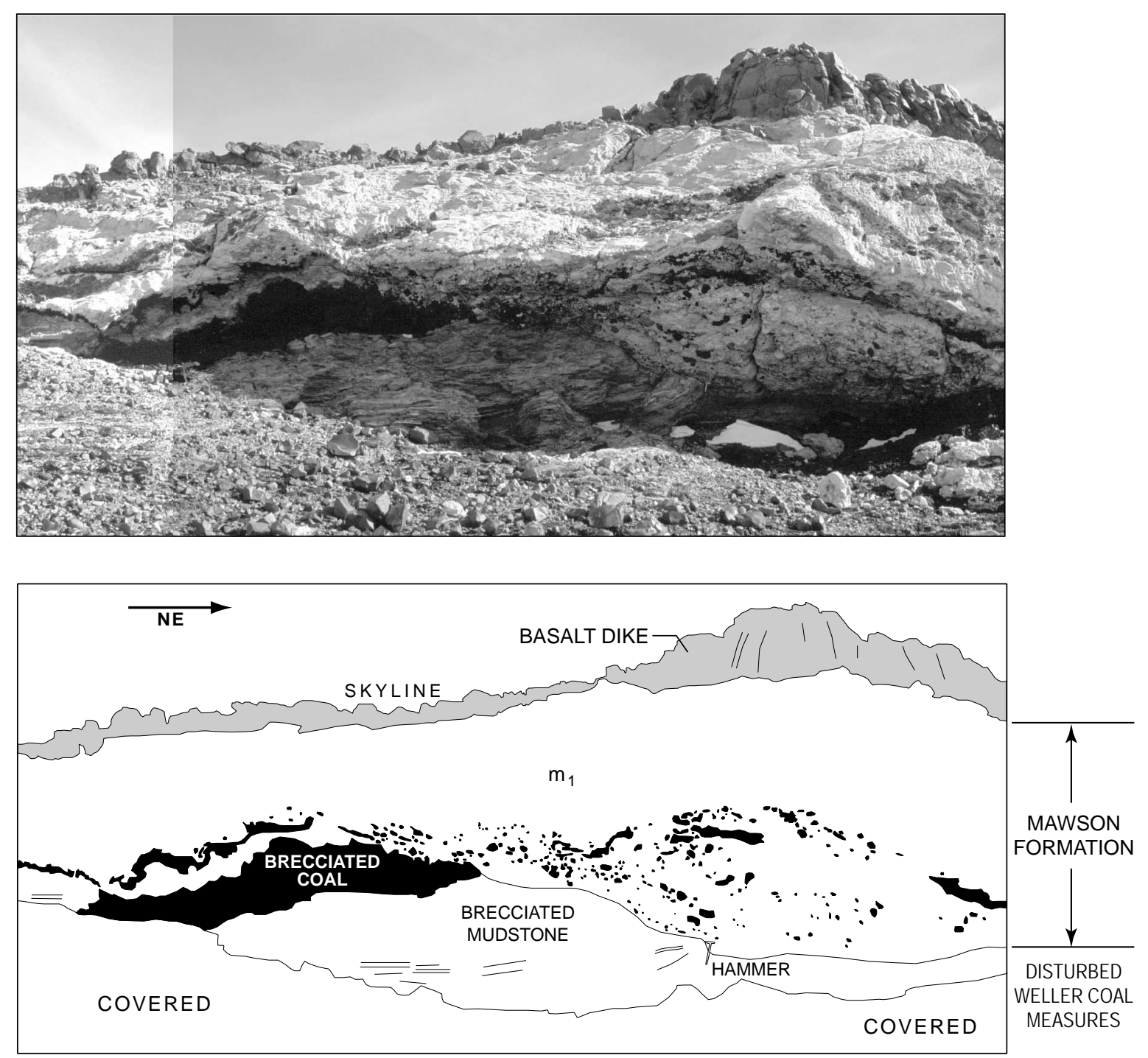

REUBI ET AL., FIG. 8 

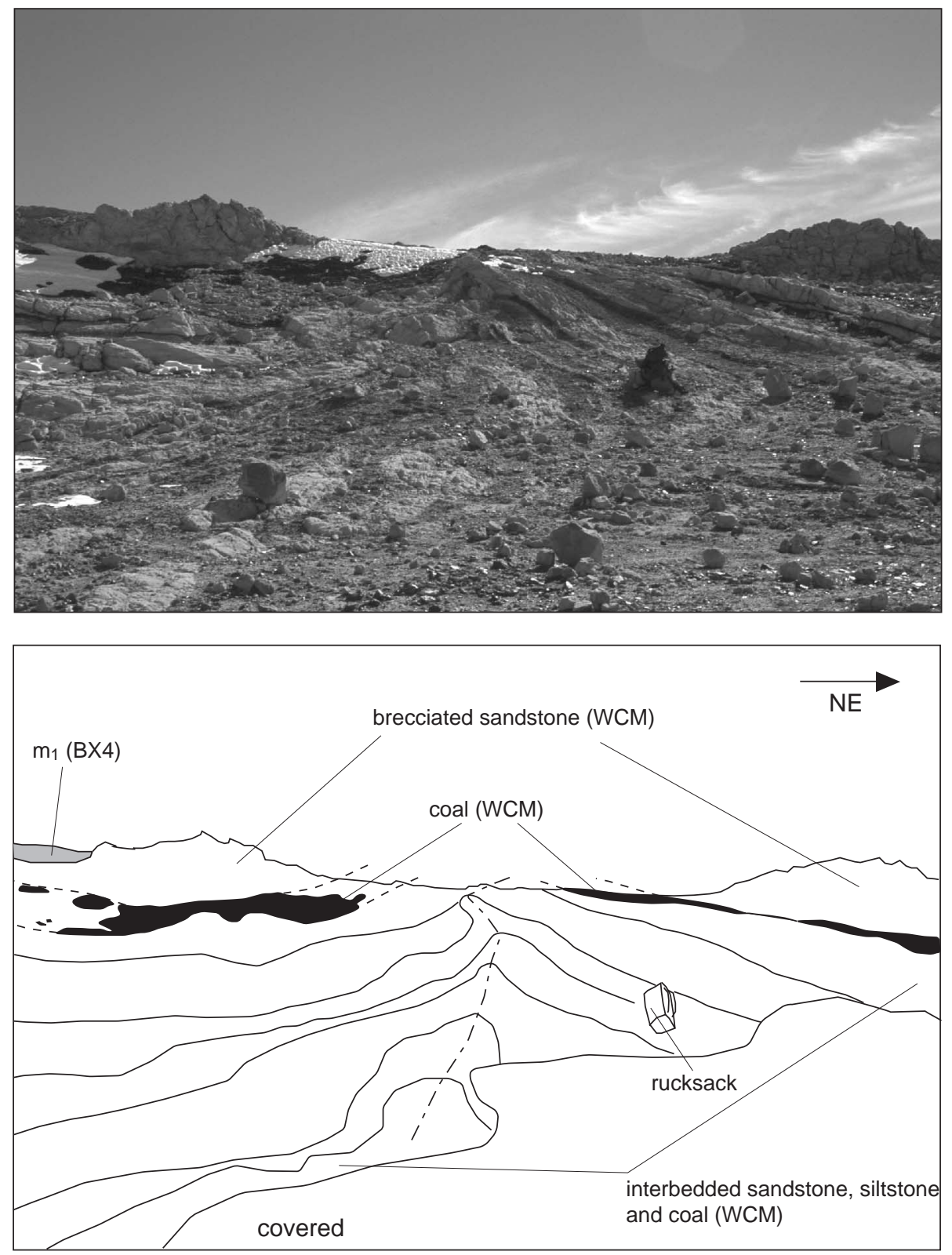

REUBI ET AL., Fig. 9 

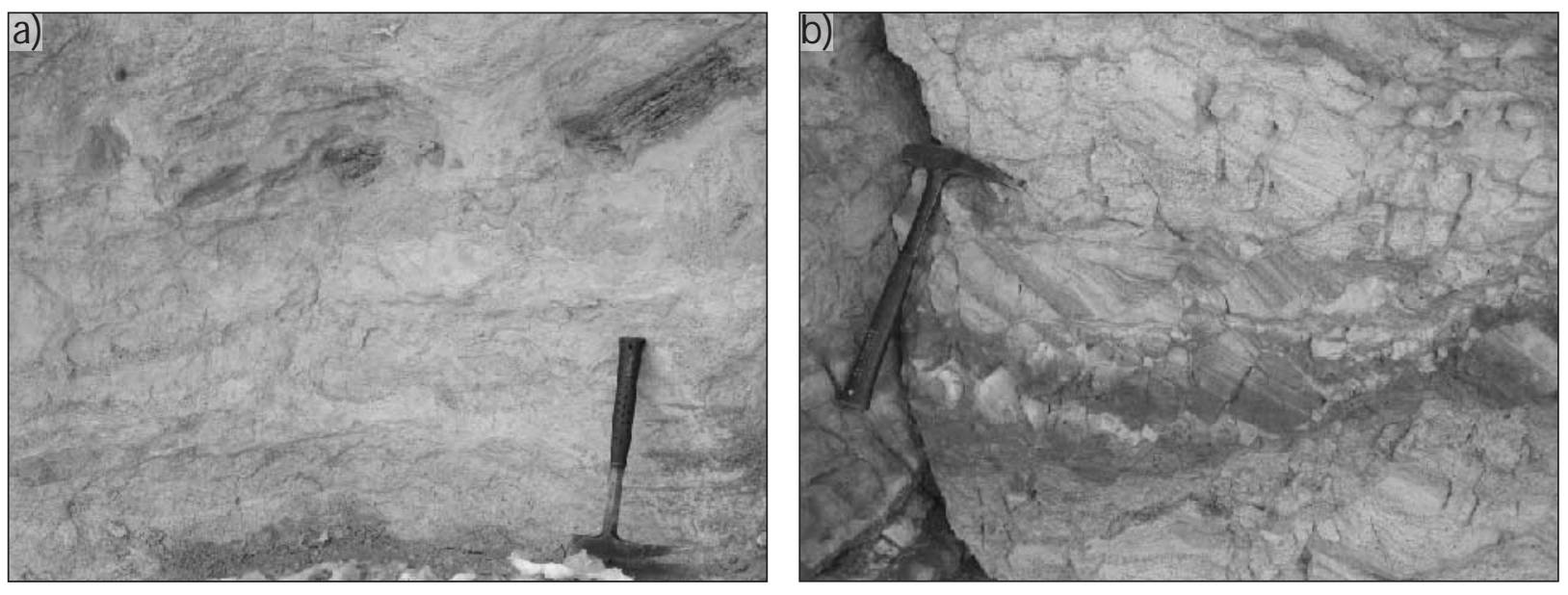

REUBI ET AL., FIG. 10 

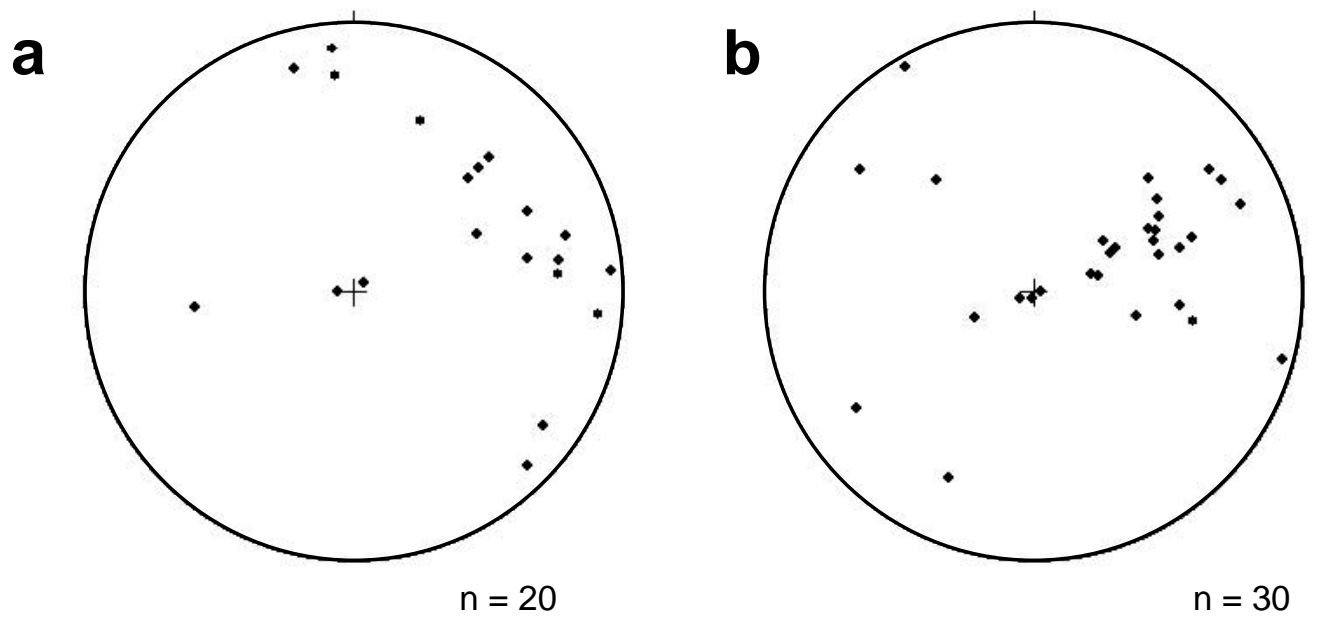

REUBI ET AL., FIG. 11 
a

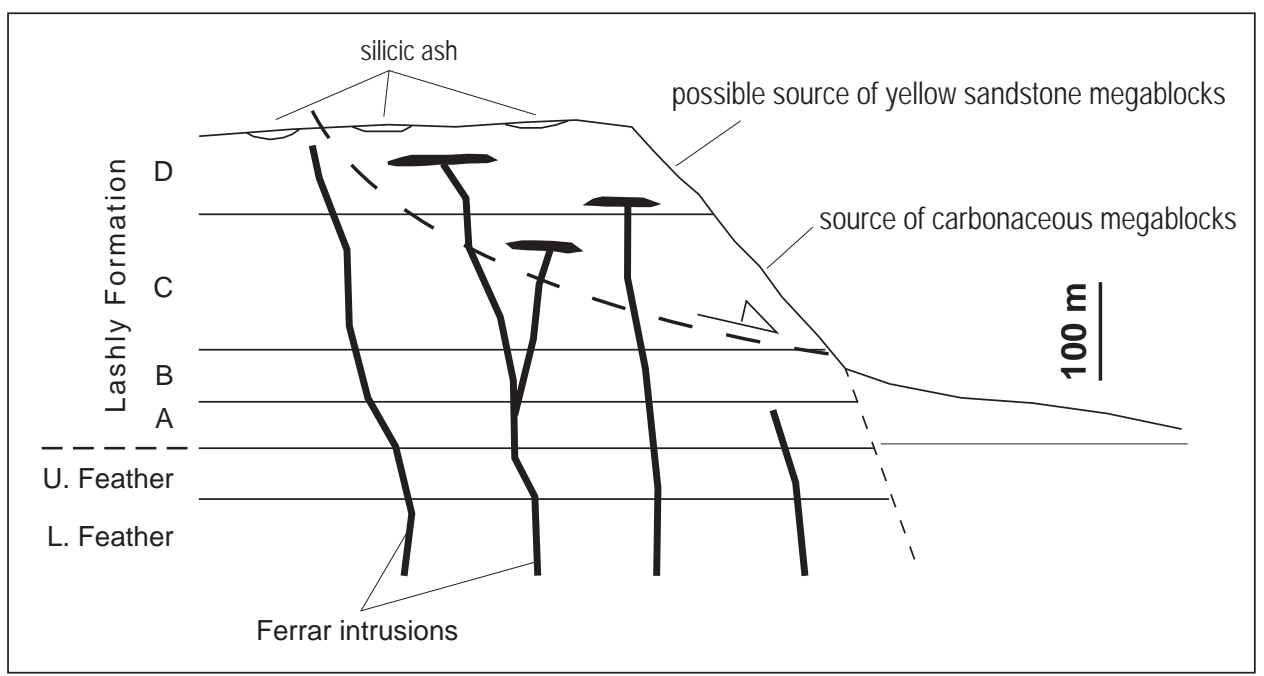

b

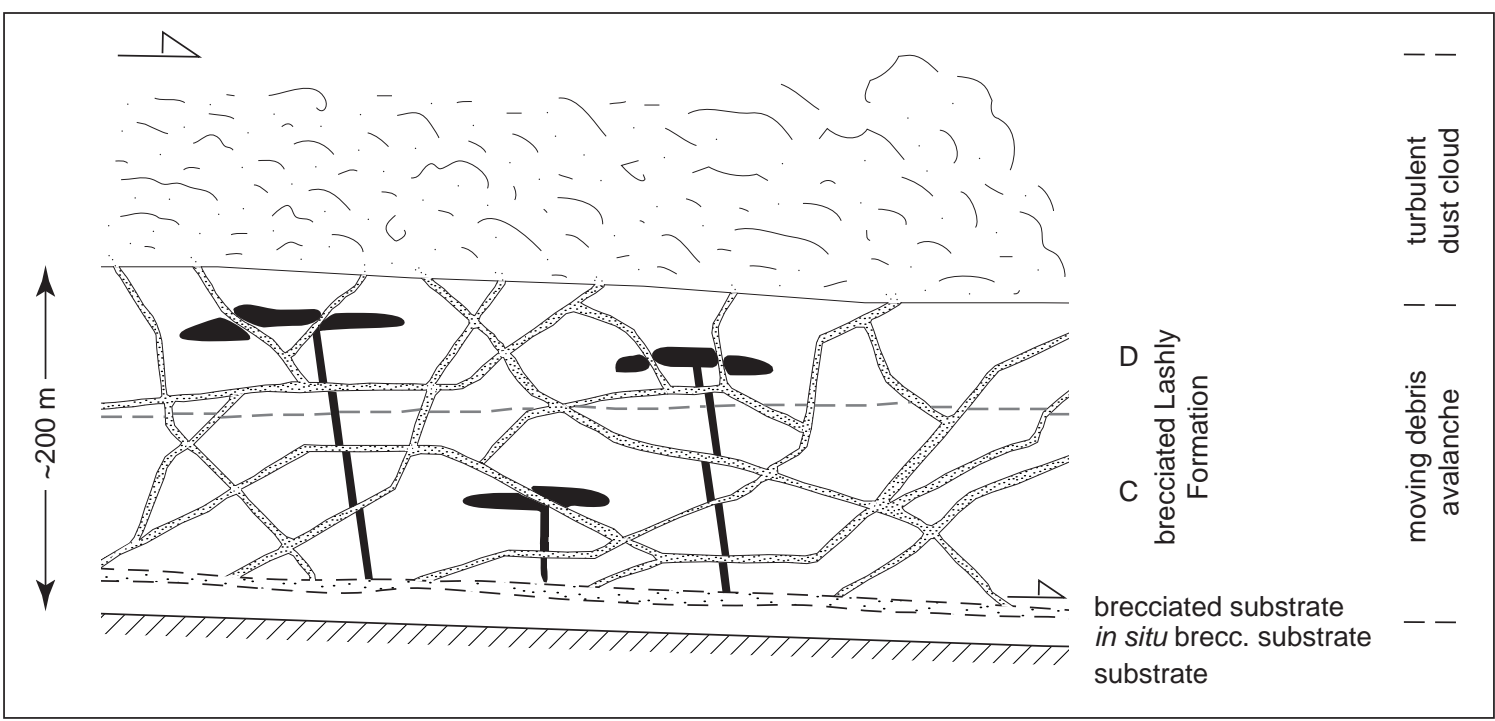

C

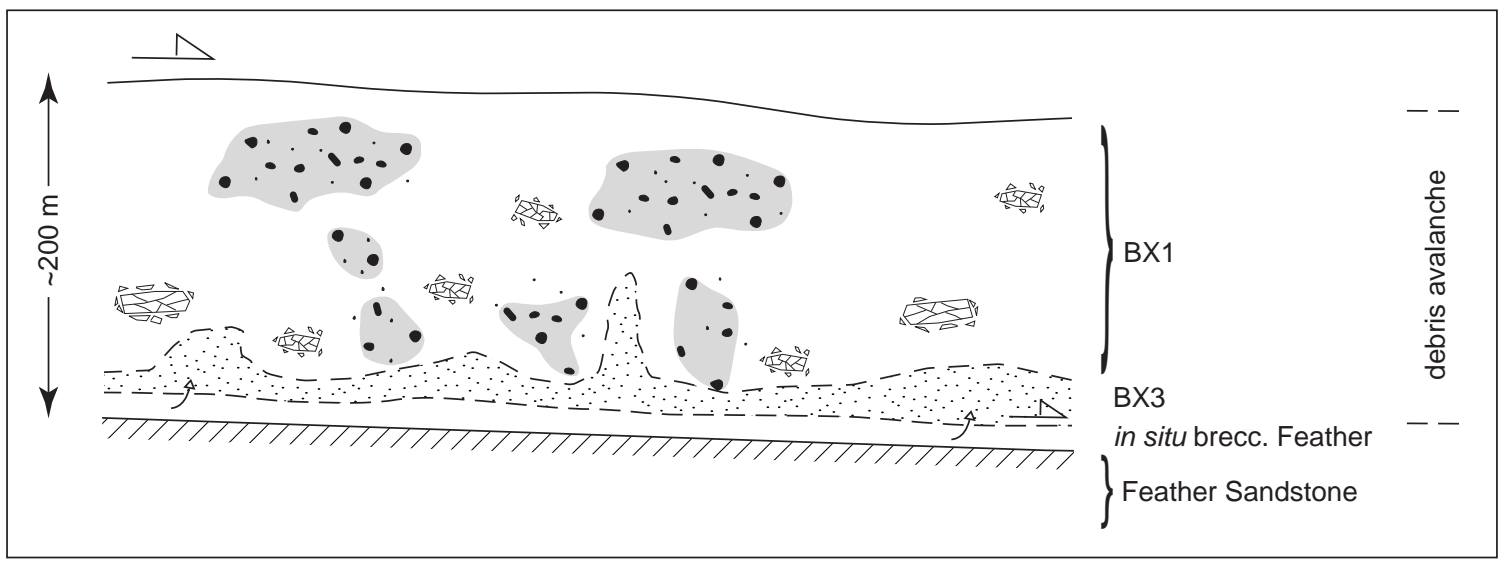

REUBI ET AL., FIG. 12 